\title{
MIGRATORY CHARACTERISTICS OF
} SPRING CHINOOK SALMON IN THE WILLAMETTE RIVER

Annual Report 1991

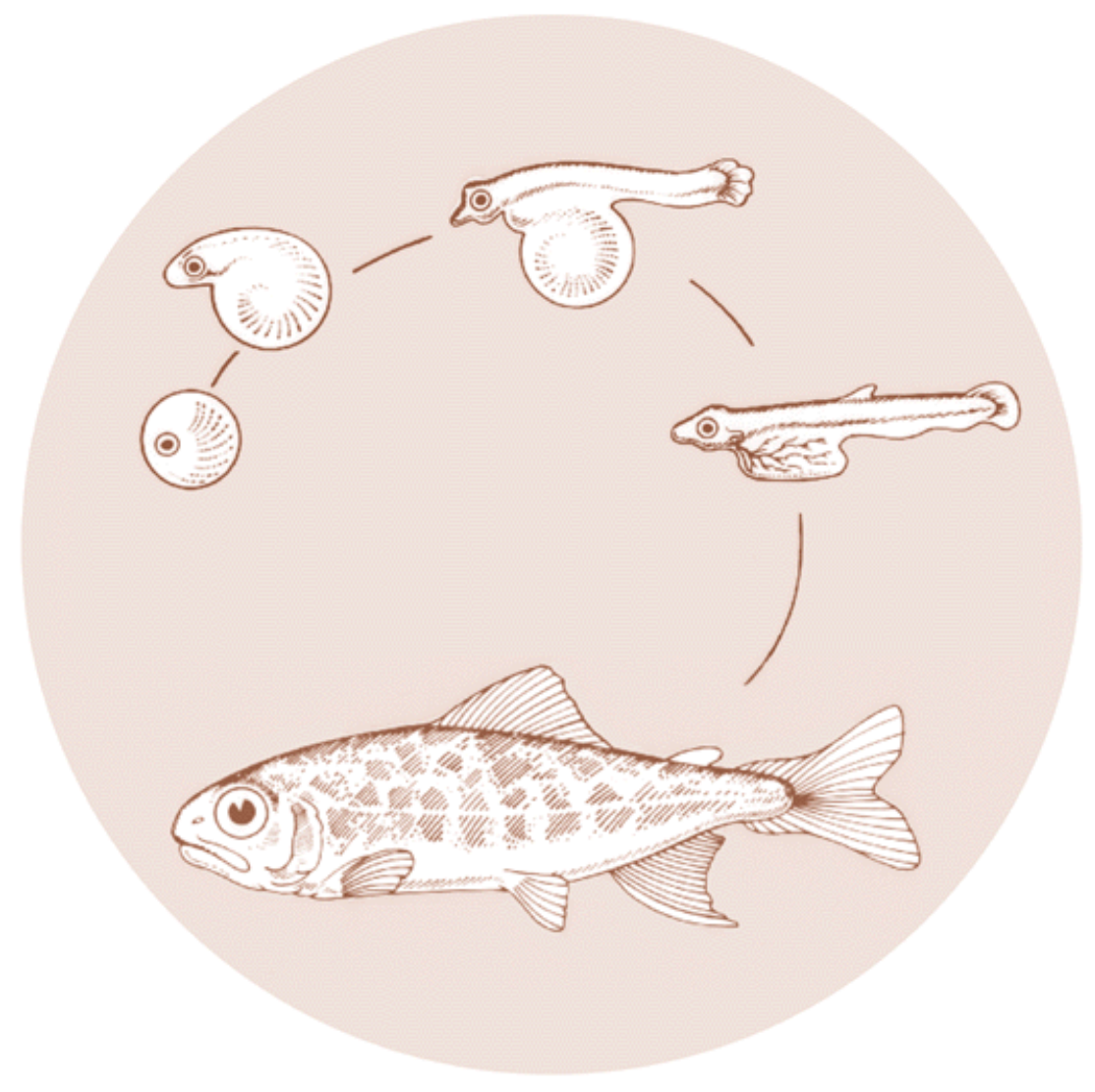

DOE/BP-92818-1 
This report was funded by the Bonneville Power Administration (BPA), U.S. Department of Energy, as part of BPA's program to protect, mitigate, and enhance fish and wildlife affected by the development and operation of hydroelectric facilities on the Columbia River and its tributaries. The views of this report are the author's and do not necessarily represent the views of BPA.

This document should be cited as follows:

John C. Snelling, Schreck, C. B., Bradford, C. S., Davis, L. E., Slater, C. H., Beck, M. T., Ewing, S. K., Oregon Dept. of Fisheries Research Unit, Dept. of Fisheries and Wildlife, Oregon State University, Migratory Characteristics of Spring Chinook Salmon in the Willamette River, 1993, Annual Report 1991 to Bonneville Power Administration, Portland, OR, Contract DE-AI79-88BP92818, Project 88-160-3, 50 electronic pages (BPA Report DOE/BP-92818-1)

This report and other BPA Fish and Wildlife Publications are available on the Internet at:

\section{http://www.efw.bpa.gov/cgi-bin/efw/FW/publications.cgi}

For other information on electronic documents or other printed media, contact or write to:

Bonneville Power Administration Environment, Fish and Wildlife Division

P.O. Box 3621

905 N.E. 11th Avenue

Portland, OR 97208-3621

Please include title, author, and DOE/BP number in the request. 


\title{
MIGRATORY CHARACTERISTICS OF SPRING CHINOOK SALMON IN THE WILLAMETTE RIVER
}

\author{
Annual Report 1991 \\ Prepared by: \\ John C. Snelling \\ Carl B. Schreck \\ C. Samual Bradford \\ Lawrence E. Davis \\ Caleb H. Slater \\ Marcus T. Beck \\ Sean K. Ewing \\ Oregon Department of Fishery Research Unit \\ Department of Fisheries and Wildlife \\ Oregon State University
}

Prepared for:

U.S. Department of Energy

Bonneville Power Administration

Environment, Fish and Wildlife

PO Box 3621

Portland, Oregon 97208

Project No. 88-160-3

Contract No. DE-AI79-88BP92818

May 1993 


\section{EXECUTIVE SUMMARY}

- The majority of juvenile spring chinook salmon released from Willamette hatchery in 1991 begin downstream movement immediately upon liberation. They travel at a rate of 1.25 to 3.5 miles per hour during the first 48 hours post-release, considerably slower than the water velocities available to them.

- Unlike the findings for 1990, no radio-tagged juveniles remained in the vicinity of the release site longer than 1.5 hours. And none delayed their migration by stopping above Willamette Falls.

- Juveniles feed actively during migration, primarily on aquatic insects.

n $\mathrm{Na}^{+} / \mathrm{K}^{+}$gill ATPase and cortisol are significantly reduced in juveniles reared in the third pass of the Michigan series with triple density and oxygen supplementation, suggesting that these fish were not as well developed as those reared under other treatments.

Returning adult spring chinook salmon migrate upstream at an average rate of about 10 to 20 miles per day, but there is considerable between fish variation.

- Returning adults exhibit a high incidence of "wandering" in and out of the Willamette River system above and below Willamette Falls.

- Adults which fall back at least once after ascending the falls comprise $12 \%$ of our adult sample. 


\section{INTRODUCTION}

This report documents work performed during the third year of the Migration Behavior Subcontract. The objective of our research is to examine in detail the migration of juvenile and adult spring chinook salmon in the Willamette River. It has two goals: (1) to determine characteristics of seaward migration of spring chinook smolts in relation to oxygen supplementation practices at Willamette Hatchery, and (2) to identify potential sources of adult spring chinook mortality in the Willamette River above Willamette Falls and use this information towards analysis of the study on efficiency of oxygen supplementation.

No information is available concerning the effects of oxygen supplementation on the migratory characteristics of juvenile salmon. This information will be necessary to assess the effectiveness of oxygen supplementation as a means of improving hatchery production on the Columbia River as a whole. Although a full evaluation of hatchery technology aimed at doubling the run size of spring chinook salmon in the Columbia River will be dependent on analysis of adult coded wire tag-return data, examination of the migratory characteristics of hatchery smolts may prove to be equally or even more informative. It will be possible to determine the rate at which individuals from various oxygenation treatment groups leave the Willamette River system, a factor which may be strongly related to adult return rate. Furthermore, this information will be available within weeks of the time of release, allowing management decisions without waiting three to five years for coded wire tag (adult return) data. Finally, since our study focuses on the freshwater phase of 
juvenile spring chinook life history, data collected will be independent of any influences associated with oceanic conditions which may vary widely from one year to the next.

In addition to serving as a means with which to assess the utility of oxygen supplementation for upper Columbia River hatcheries, our study on the Willamette Hatchery stock will provide background information required to effectively utilize increased production within the goals of the Willamette Fish Management Plan. Such information includes: (1) the length of the latent period (if any) after release from the hatchery but before migration begins, (2) migration rates in the river, (3) the extent of juvenile spring chinook residualism in the Willamette River (if any), (4) the physiological quality and feeding of outmigrants, and (5) the degree of predation to which migrants or residuals are exposed.

The overall approach. has been to gain a general understanding of out-migrant behavior exhibited by juvenile spring chinook salmon reared at Willamette Hatchery" according to "traditional'! rearing practices during the last two years, before the implementation of oxygen supplementation and experimental rearing regimes (see Annual Reports 1989 and 1990). During this past year we used the results obtained in 1989 and 1990 to formulate a tagging, collection, and sampling program for juveniles reared at Willamette Hatchery according to different treatments of rearing density and oxygen supplementation.

In addition to characterizing the seaward migration of juvenile spring chinook salmon, information on the spawning migration of returning adults in the Willamette River also measures hatchery 
efficiency. The overall oxygenation study at Willamette Hatchery is dependent on a tight experimental design relating hatchery practices (experimental rearing regimes) and adult tag returns. Our study of adult migration will provide data which should assist in determining the number and frequency of expected tag returns at the hatchery.

Finally, in past years up to $50 \%$ of the adult spring chinook salmon recorded past Willamette Falls have remained unaccounted for upstream (1987, Bonneville Power Administration Program Measures, Section 600). This study will attempt to determine the reason for the apparent loss, and suggest strategies to overcome the problem.

\section{MATERIALS AND METHODS}

Tasks undertaken included: (1) evaluating the physiological responses of Willamette Hatchery smolts (control and experimental rearing regimes) to crowding, loading, truck transport, and release in the upper Willamette River below Dexter Dam, (2) radio-tracking outmigrant juvenile spring chinook salmon reared according to control and experimental rearing regimes at Willamette Hatchery, (3) recapturing outmigrant juveniles in the vicinity of Willamette Falls (i.e., in the lower Willamette River), (4) surveying selected river sites (upper, middle, and lower Willamette River) for the presence of juvenile spring chinook salmon over an extended time period following the release of production fish from Willamette Hatchery (possible "residual" non-migrants), and (5) radio-tracking returning adult spring chinook salmon trapped, radio-tagged, and released at Willamette Falls (lower Willamette River) during various phases (early, middle, and late) of the spawning migration. 
Physiological Response of Willamette Hatchery-Reared Juvenile Spring Chinook Salmon to Collection, Transportation, and Release: Evaluation of Plasma Cortisol Levels in Control and Experimental Treatments

This third year of the migration study represents the first year in which oxygen supplementation practices were implemented at Willamette Hatchery. Accordingly, we expanded the scope of the study to include juvenile fish reared in control and experimental rearing regimes (treatments). The following treatment groups were chosen for study (for each group the two ponds represent replicate treatments) :

1) Ponds \#7 and \#17: Standard Ponds (Controls): fish reared under conditions of "standard" density ( $1 \mathrm{lb} / \mathrm{ft}^{3}$ at release) without $\mathrm{O}_{2}$ supplementation

2) Ponds \#9 and \#19: Triple Density Ponds; fish reared under conditions of $3 \times$ standard density $\left(3 \mathrm{lb} / \mathrm{ft}^{3}\right)$ with $\mathrm{O}_{2}$ supplementation

3) Ponds \#10 (North and South): Third Series Michigan Ponds: fish reared in the third pass of the "Michigan Series" under conditions of triple density with $\mathrm{O}_{2}$ supplementation

We monitored the physiological responses of hatchery-reared spring chinook salmon to the combined physical processes of crowding fish in the hatchery raceway, loading onto a transport truck, trucking to the liberation site, and release into the upper Willamette River below Dexter Dam (fish released at Pengra Ramp, River Mile 201). Plasma cortisol concentrations were measured before and after collection and transport in order to assess the activity of the hypothalamic-pituitary-inter-renal axis (Donaldson, 1981) and thereby 
gain some insight into the degree of stress experienced by fish subjected to these handling procedures. It is generally accepted that plasma cortisol levels provide a reliable index of the primary, or neuroendocrine, response to acute stress (Mazeaud et al., 1977). Cortisol was also monitored to provide insight into the developmental stage of the fish since cortisol concentration is dynamic during the process of smoltification (Barton et al., 1985).

We collected blood samples from juvenile fish reared in ponds \#7, \#9, and \#10 South; fish from the corresponding replicate ponds (\#17, \#19, and \# 10 North) were used in the radio telemetry migration study described below. Samples from 20 fish per pond were taken on 28 February 1991 between the hours of 0730 and 1000 (prior to crowding) in order to establish "resting" cortisol levels. For each pond, in turn, hatchery personnel crowded fish to one end of the raceway, netted samples of fish $(\mathrm{N}=100-200)$ for pre-liberation weight determinations, and loaded (pumped fish from the raceway up into) transport trucks. A second tissue-sampling crew was stationed at the liberation site (Pengra Access), where a second set of blood samples $(N=20 /$ pond) was taken immediately as fish were being liberated from the truck into the Willamette River.

For plasma cortisol determinations all fish were quickly netted and placed immediately into a bucket containing a lethal dose of MS-222 (200 mg/liter) buffered with $\mathrm{NaHCO}_{3}(500 \mathrm{mg} /$ liter). Individual fish were bled by severing the caudal peduncle and blood collected in ammonium-heparinized capillary tubes. Plasma was separated by centrifugation and temporarily stored on dry ice until it could be returned to laboratory facilities at Oregon State University, where it 
was stored at $-20^{\circ} \mathrm{C}$ until time of assay. Plasma cortisol was measured directly in $10 \mu \mathrm{l}$ of plasma following the radioimmunoassay procedure of Foster and Dunn (1974), as modified by Redding et al. (1984).

In addition to monitoring the physiological responses of juvenile spring chinook to the stress associated with crowding, loading, transportation, and release, we made an effort to assess one physiological index of smoltification characterizing fish reared at Willamette Hatchery according to the different rearing regimes. Changes in the gill content/activity of $\mathrm{Na}^{+} / \mathrm{K}^{+}$ATPase are believed to be one such index, as the ability of anadromous species to successfully adapt to the seawater environment may be dependent on an augmentation of the activity of this enzyme prior to seawater entry (Giles and Vanstone, 1976). We dissected gill tissues from all of the fish described above (pre-crowding and post-transport/liberation) in order to establish $\mathrm{Na}^{+} / \mathrm{K}^{+}$ATPase activity in pre-migrant fish. Specifically, gill filament tissues were dissected from the cartilage of six gill arches (three arches from each side) and placed into $1 \mathrm{ml}$ of gill enzyme buffer. Tissues in buffer were frozen on dry ice until they could be transported to O.S.U., where they were stored at $-80^{\circ} \mathrm{C}$. Finally, gill tissues were transferred on dry ice to laboratory facilities operated by the National Marine Fisheries Service in Cook, WA., where they were analyzed for $\mathrm{Na}^{+} / \mathrm{K}^{+}$ATPase activity according to the method of Zaugg (1982). This aspect of the work also allows us to network with the smolt quality monitoring study funded by BPA. 


\section{Radio-Tracking Outmigrant Juvenile Spring Chinook Salmon}

Radio transmitters and radio receivers (equipped with hand-held loop antennas) used for tracking fish were purchased from Advanced Telemetry Systems, Inc. (Isanti, MN). In addition to the receivers used for tracking fish (ATS Challenger Model 2000), we employed a data logger (digital recorder) connected to a long-range yagi antenna for the untended collection of telemetry data in the lower Willamette River. The data logger (Model SRX-400, Configuration 3) was purchased from Lotek Engineering (Aurora, Ontario, Canada): the yagi antenna was purchased from Advanced Telemetry Systems.

Transmitters (juvenile fish, stomach implant) were chosen to operate in the 48-50 megahertz bandwidths; individual transmitter frequencies were separated by a minimum of 10 kilohertz to insure that each tag could be unambiguously identified.

On 26 February 1991, 20 fish each from ponds \# 17 (standard density without supplemental $\mathrm{O}_{2}$ ), \#19 (triple density with $\mathrm{O}_{2}$ supplementation), and \#10 North (third series Michigan: triple density with $\mathrm{O}_{2}$ supplementation) were netted, lightly anesthetized (MS-222, $50 \mathrm{mg} /$ liter buffered with NaHC03, $100 \mathrm{mg} / \mathrm{l}$ ) and tagged with 14-day stomach implant radio transmitters (transmitters equipped with batteries designed to power a continuous pulsed signal for a minimum of 14 days) following the protocol of Ward and Miller (1988). During this procedure, fish shorter than $17 \mathrm{~cm}$ fork length were rejected; this insured that the weight of radio transmitters $(1.2 \mathrm{~g}$ in water) represented no more than $2 \%$ of the total fish wet weight. As fish reared in the experimental ponds were, on the average, smaller than fish reared in standard ponds (Joe Sheehan, ODFW, pers. 
comm.), fish used in the radio telemetry study were biased towards the high end of size-frequency distributions. The average length of all fish tagged with radio transmitters was $18.2 \mathrm{~cm}$ : average sizes of tagged fish did not differ significantly among ponds representing different treatments.

In order to monitor recovery from the tagging procedure and check for tag retention, all tagged fish were temporarily sequestered in perforated 120 liter tanks suspended in pond \#16 (one-half standard density without supplemental $\mathrm{O}_{2}$ ) until 28 February, at which time they were quietly liberated into this raceway. Pond \# 16 was chosen for temporary holding to insure that all radio-tagged fish could be loaded onto the same liberation truck and released together. On 1 March, 59 unique radio signals could be detected in the vicinity of the raceway into which 60 tagged fish had been returned (one signal could not be detected). On this date, all fish were transported about 45 minutes by truck to Pengra Access point and released.

The tracking strategy we adopted was to monitor the downstream progress of a majority of tagged fish, and if possible stay in front of the fastest fish. Initially, a tracking crew remained at the liberation site and documented the behavior of released fish by noting the times at which individuals departed the immediate vicinity and began to move downstream out of range (i.e., the times at which signals were "lost"). After a majority of the tagged fish had left the liberation site, this crew proceeded downstream to the first of eight pre-established fixed riverbank tracking stations. These stations were established at Clearwater boat ramp [river mile (PM) 191], Beltline Bridge (Eugene, RM 178), Harrisburg (RM 161), Willamette Park (Corvallis, RM 134), 
Willamette Mission Park (RM 72), and Bemert banding (West Linn, RM 28).

At each station, fish passage was documented by monitoring a scanning, programmable receiver (Advanced Telemetry Systems Challenger Model 2000) into which all 60 radio frequencies had been stored in memory. The mean pulse rate of juvenile fish radio transmitters was 61 pulses per minute: scan intervals of four seconds per frequency allowed the unambiguous detection of audible signals when fish were in range. A loop receiving antenna mounted on a PVC tripod was situated on the riverbank and oriented at an angle of approximately $45^{\circ}$ with respect to the direction of water flow. The time at which a particular fish first came into range was noted, as was the time at which that same fish could no longer be detected. After a given fish had moved downstream out of range, the radio frequency identifying that individual was deleted from the receiver memory, so as to maximize scanning efficiency of remaining upstream frequencies.

In addition to these fixed riverbank tracking stations, we employed mobile boat tracking platforms, where appropriate, to locate individual fish in the lower river. An untended data logging station was also established on the premises of the Oregon City Marina, located on the east bank of the Willamette River at River Mile '27.5 (one mile above Willamette Falls).

Employing four crews of two persons each and staggering the time of day worked by each crew it was possible to monitor the downstream progress of outmigrants 24 hours a day for the first three days postrelease. An effort was made to follow as many of the tagged fish as far downstream as possible. 


\section{Recapture of Outmigrant Juvenile Spring Chinook Salmon Above Willamette Falls}

We used beach seines (106.7 meters long X 2.4 meters deep) in the vicinity of Peach Cove (KM 32; approximately five miles above Willamette Falls) to sample for the presence of outmigrant juvenile spring chinook salmon during March, 1991. The target group of fish was the majority of the 1990 brood year production out of Willamette Hatchery, which were released into the upper Willamette River (at Pengra Ramp, RM 201) on 28 February. The release of fish including those with radio tags was one day later, on 1 March. Beach seining activities were conducted between 8, 15 and 22 March. On each of three dates, a crew of five persons working out of a Boston Whaler made five sets. Total numbers of fish taken were recorded, and where large numbers (i.e., > 10) of juvenile spring chinook salmon were seined, gill tissues were sampled (as described above) and preserved for subsequent analysis of $\mathrm{Na}^{+} / \mathrm{K}^{+}$ATPase activity.

\section{Evaluation of Juvenile Spring Chinook "Residualism"}

Selected Willamette River sites in the upper, middle, and lower river were surveyed for the presence of juvenile spring chinook from mid-March through mid-April. Surveys in the "upper" river were concentrated in the immediate vicinity of the Willamette Hatchery 1990 brood year release [Dexter Dam and Pengra Access point): surveys of the "middle" river were conducted between the Buena Vista boat ramp and the lower end of Wells Island (approximately RM 106);

surveys of the "lower" river focused on the region just above Willamette Falls, at the mouth of the Tualatin River near Bernert Landing (KM 28) 
and in the sloughs behind Rock Island (RM 30). Most of the survey work was carried out by electrofishing out of a shock-boat: on several occasions and at various locations hook-and-line methods were employed in the sampling protocol.

In addition to recording numbers of juvenile spring chinook salmon taken at a given site on a particular date, gill tissues were sampled (as described above) for analysis of $\mathrm{Na}^{+} / \mathrm{K}^{+}$ATPase, and carcasses were preserved in $10 \%$ formalin for subsequent analysis of gut-contents. After carcasses were adequately fixed in formalin $>10$ days), they were transferred to $40 \%$ isopropanol. Gut contents were placed in $10 \mathrm{cc}$ vials, and total volumes were estimated by comparing tbe settled vial contents-with a calibrated "standard" vial. Finally, a qualitative analysis of gut contents was carried out by viewing vial contents at low power magnification under a dissecting microscope.

\section{Radio-Tracking Returning Adult Spring Chinook Salmon}

Adult spring chinook salmon were captured in the lower Willarnette River at Willamette Falls, tagged with stomach implant radio transmitters, released, and tracked upstream (or, in some cases, downstream) using equipment described above. Three separate groups were captured and tagged in April, May, and June of 199 1, chosen to represent the early, middle, and late phases (respectively) of the adult run. In addition to describing the general migratory tendencies of returning adults in the Willamette River, we investigated the possibility that different phases of the run might exhibit specific differences or characteristic patterns with respect to migratory behavior (i.e., rate of movement, extent or success of migration, etc.). 
Radio-tracking early run adults this year began on 23 April. We attempted to collect fish representing this phase of the run on an earlier date (16 April), but were unsuccessful, as no fish (except steelhead) were passing through the cul-de-sac leg of the fishway at that time. Between 16 April and 15 May, Portland General Electric's Sullivan Plant suspended operations: this resulted in little or no attraction water in the cul-de-sac leg of the fishway, and a concomitant decline in the number of fish using this part of the fish ladder (although approximately 300 fish per day were passing the Falls through the other two legs of the fishway). Since the cul-de-sac is the only leg of the fishway at Willamette Falls equipped with a trap facility, it was necessary for us to collect early run spring chinook salmon using an alternative approach to that offered by the ODFW trap. On 23 April the fishway was de-watered (to allow personnel to clean the window for the main fish viewing room): during this time we were permitted to climb down into the ladder and sequester 27 adult spring chinook into a shallow pool. A small (approximately 34 liters) plastic tub was employed as an anesthetic bath (MS-222, $50 \mathrm{mg} / \mathrm{liter}$ buffered with $\mathrm{NaHCO}_{3}, 100 \mathrm{mg} /$ liter). Fish were netted and immediately transferred to this tub, where they were lightly anesthetized, measured (fork lengths recorded to the nearest $0.5 \mathrm{~cm}$ ), and fitted with 70-day stomach implant radio transmitters (ATS, Isanti, MN; average weight in water $=11 \mathrm{~g}$ ). These fish were not weighed and scale samples were not taken. Immediately following the tagging procedure, fish were returned to the fishway and, monitored for recovery. 
Adult spring chinook salmon representing the middle and late phases of the 1991 return were captured in the cul-de-dac leg of the Willamette Falls fishway using the ODFW trap. We following the collection and tagging protocols employed last year. Radio-tracking middle run adults was initiated on 28 May; 28 fish were diverted from the fishway into the trap anesthetic bath (MS-222 buffered with $\mathrm{NaHCO}_{3}$ ), where they were measured, weighed, and fitted with stomach implant radio transmitters. Scale samples (two scales from above the lateral line just anterior of the dorsal fin taken from each side) were collected for the subsequent determination of fish age. Immediately following the tagging procedure, fish were gently lifted from the bath into a recovery trough, from which they could volitionally re-enter the fishway.

Radio-tracking late run adults was initiated on 26 June; 30 fish were captured, tagged, and liberated as described above.

For the most part, the upstream (in some instances, downstream) progress of radio-tagged adults was monitored from a jet boat, which could be used safely between Eugene and the Columbia River. A drift boat was used in the upper river (between Dexter Dam and Eugene) to check for the presence of tagged fish believed to be in the river above Eugene. Tracking was carried out in a fashion similar to that described above for juveniles. In this case, the loop antenna tripod was mounted in the bow of the boat, and aerial photographs (U.S. Army Corps of Engineers) along with river maps (Willamette River Recreation Guides, supplied by the Oregon State Marine Board) were used to establish fish locations to the nearest one-half mile. The mean pulse rate of adult fish transmitters was 120 pulses per minute; 
receiver scan intervals as brief as two seconds per frequency allowed the unambiguous identification of individual fish, once in range. In addition to boat tracking platforms, two untended data-logger/yagi antenna recording stations were established. One of these was set up just below Bonneville Dam on the Columbia River; the other was located at Dexter Pond (Willamette River, RM 203).

\section{RESULTS AND DISCUSSION}

Physiological Response of Willamette Hatchery-Reared Juvenile Spring Chinook Salmon to Collection, Transportation, and Release: Evaluation of Plasma Cortisol Levels in Control and Experimental $\left(\mathrm{O}_{2}\right)$ Treatments

Plasma cortisol levels characterizing Willamette Hatchery smolts before and after crowding, loading, truck transport, and liberation are summarized in Figure 1. Cortisol levels in fish sampled pre-release at Willamette Hatchery (resting levels) were significantly higher (p c 0.05) in fish reared in Pond \#7 under conditions of standard density without supplemental oxygen $(19.0 \pm 5.0 \mathrm{ng} / \mathrm{ml})$ than in fish from Pond \#10 South, reared under conditions of triple density with supplemental $\mathrm{O}_{2}$ in the third pass of the Michigan Series $(6.2 \pm 1.3$ ng/ml). Resting cortisol levels in fish from Pond \# 9 (triple density with supplemental $\mathrm{O}_{2}$ ) tended to be intermediate between the other two treatment groups $(11.6 \pm 2.8 \mathrm{ng} / \mathrm{ml})$, but were not statistically different from either.

In all three treatment groups, cortisol levels in fish subjected to normal handling and liberation procedures were significantly elevated post-transport, compared with resting levels. Post-transport cortisol levels were'higher $(\mathrm{p}<0.05)$ in fish from Pond \#7 $(126.7 \pm 9.0 \mathrm{ng} / \mathrm{ml})$ 


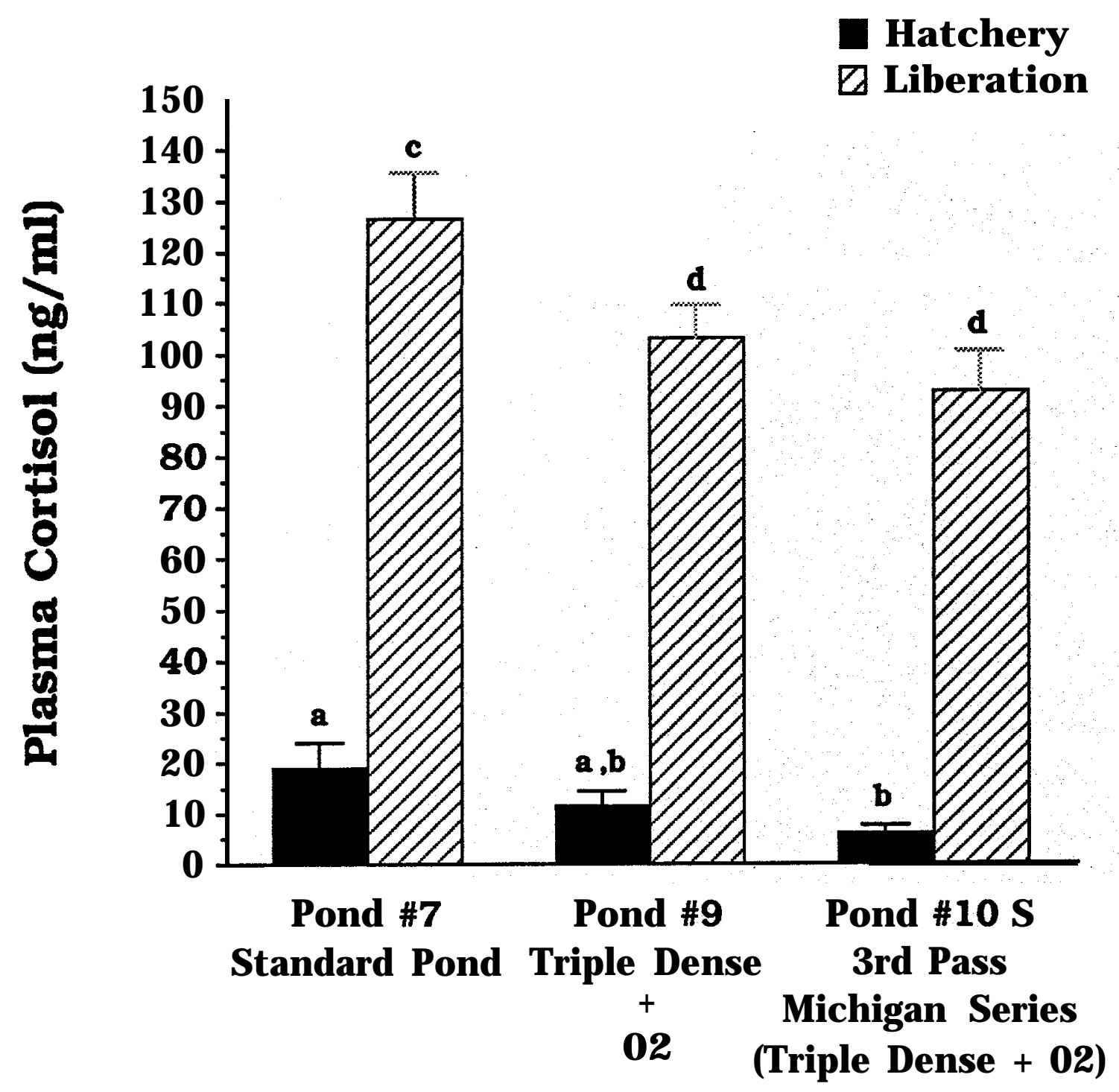

Treatment

Figure 1. Plasma cortisol levels in juvenile spring chinook salmon (Willamette Hatchery, 1990 brood-year) before (Hatchery) and after (Liberation) raceway crowding, truck loading, truck transport, and release at Pengra Ramp (Willamette River Mile 201) on 28 February, 199 1. Histogram bars indicate the mean $+\mathrm{SE} ; \mathrm{N}=20$ for all. Pre-liberation and liberation samples from the same rearing treatment were compared using paired $t$ tests; samples from different rearing treatments were compared using unpaired $t$ tests. Bars labelled with different letters are statistically different ( $\mathrm{p}<0.05)$. 
than Ponds \#9 $(103.1 \pm 6.3 \mathrm{ng} / \mathrm{ml})$ and \# 10 South $(92.7 \pm 7.9 \mathrm{ng} / \mathrm{ml})$. Post-transport cortisol levels in fish from the two triple density groups did not differ significantly.

The rapid elevation of plasma cortisol in fish as an indicator of stress resulting from various capture, transport, and stocking or release practices is well established (Barton et al., 1980; Maule et al., 1988). Acute, or short-term, increases in plasma corticosteroids (and. catecholarnines) are considered to have evolved as an adaptive mechanism, enabling individuals to meet the increased energy demands often associated with stress (Selye, 1950). In several teleost species, cortisol appears to exert a regulatory influence over the mobilization of stored energy reserves by stimulating the biochemical pathways associated with gluconeogenesis (Butler, 1968; Leach and Taylor, 1980). glycogenesis (Swallow and Fleming, 1970), and protein catabolism (Storer, 1967; Freeman and Idler, 1973). On the other hand, chronic, or long-term, elevations of plasma cortisol levels are probably deleterious. Hypersecretion of glucocorticoids is often associated with general suppression of the immune system and increased susceptibility to disease (Ellis, 198 1).

\section{Radio-Tracking Outmigrant Juveniles}

Results of the radio telemetry study conducted with juvenile spring chinook salmon outmigrants are presented in Figures 2 through 5. Data are expressed as distance travelled downstream as a function of time: the slope of any line gives average velocity travelled by an individual fish over a given stretch of river. Fish velocities derived 


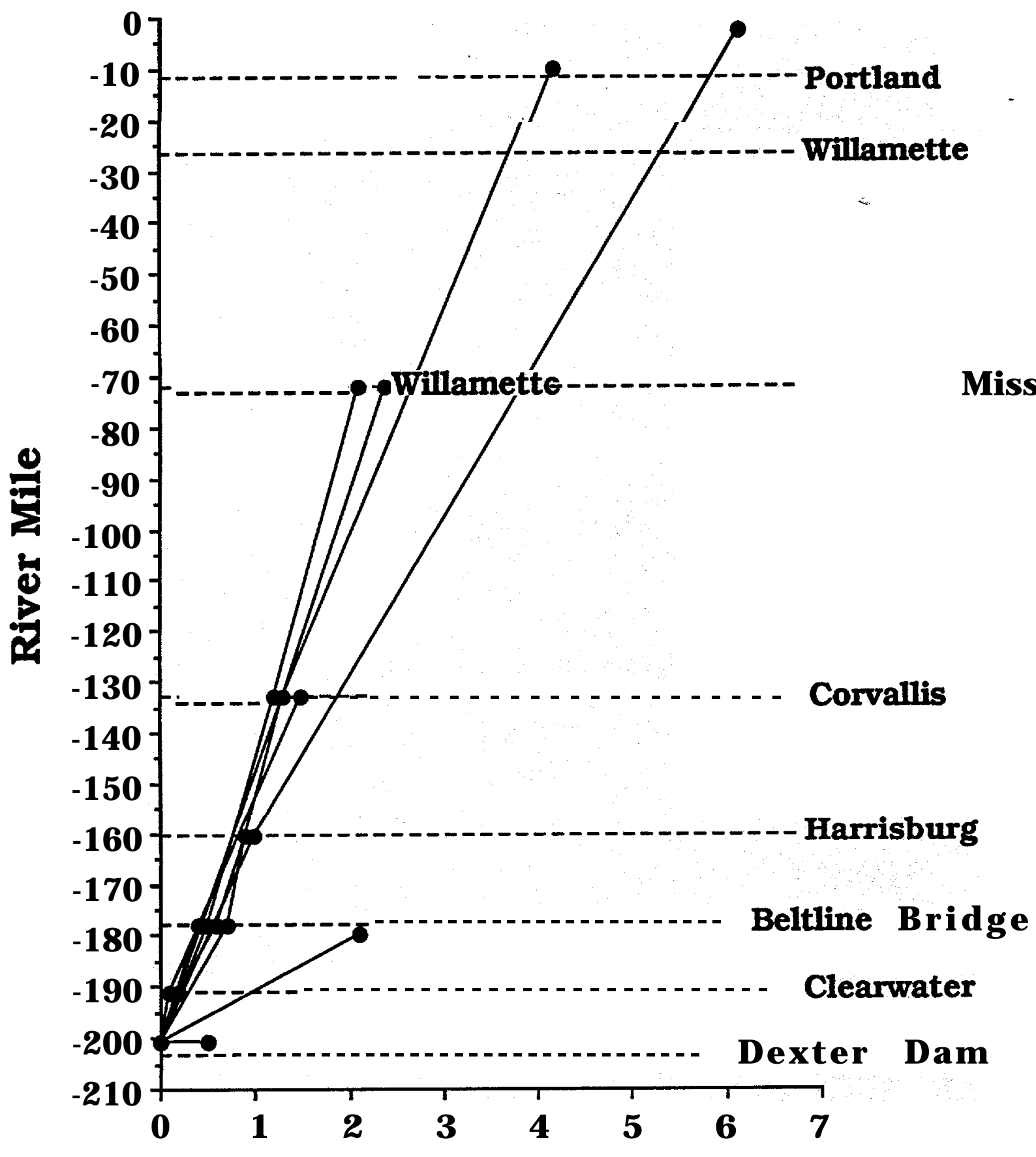

Days Post-Release

Figure 2. Movement patterns observed for radio-tagged juvenile spring chinook salmon reared at Willamette Hatchery (1990 brood-year) in Pond \# 17 (standard density without 02 supplementation) and released at Pengra Ramp (Willamette River Mile 201) on 1 March 1991. $\mathrm{N}=15$ (20 fish were tagged: five tags not located after release were deleted from the data set) . 


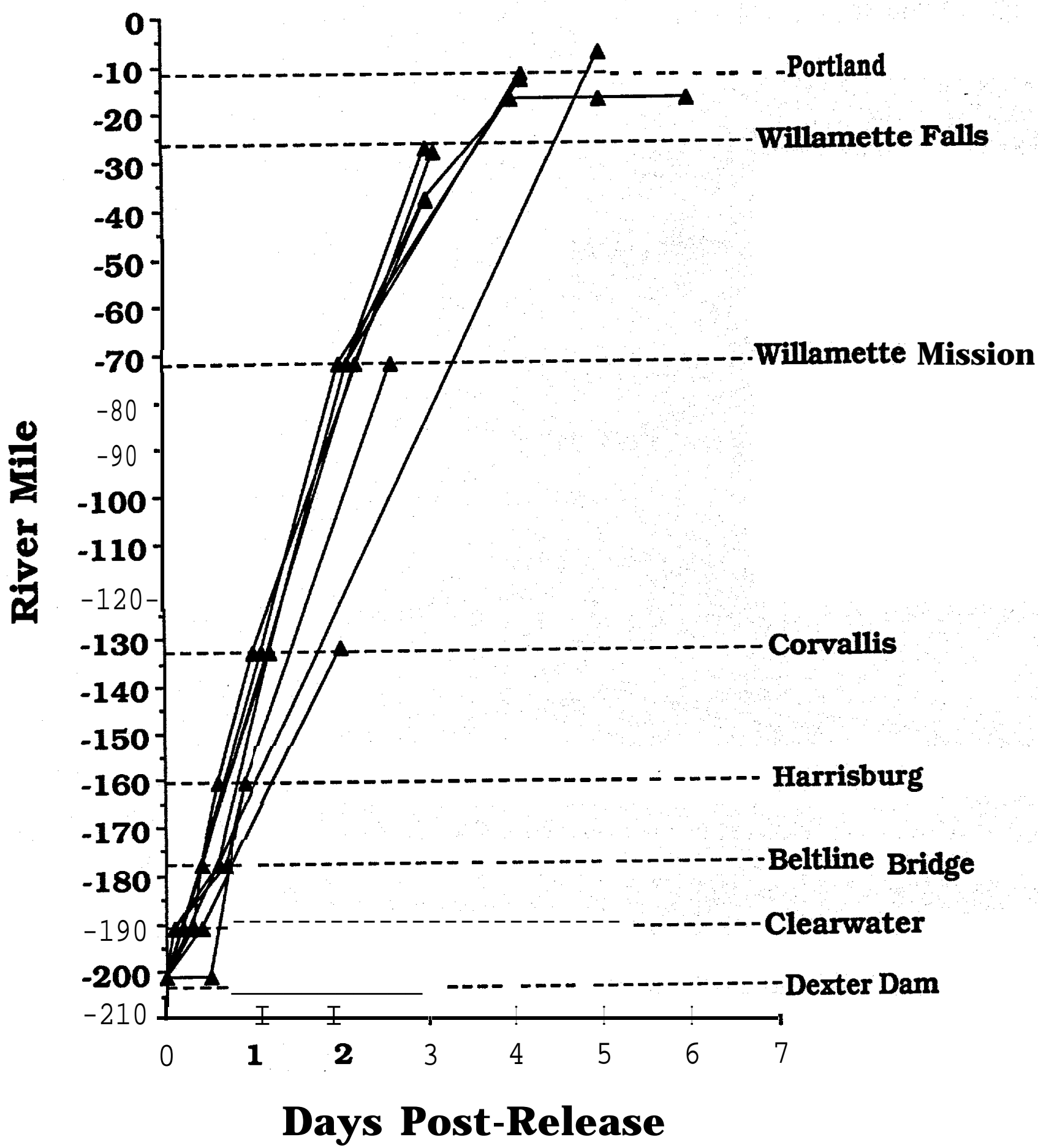

Figure 3. Movement patterns observed for radio-tagged juvenile spring chinook salmon reared at Willamette Hatchery (1990 brood-year) in Pond \# 19 (triple density with $\mathrm{O}_{2}$ supplementation) and released at Penga Ramp (Willamette River Mile 201) on 1 March 1991. $\mathrm{N}=12$ (20 fish were tagged; eight tags not located after release were deleted from the data set). 


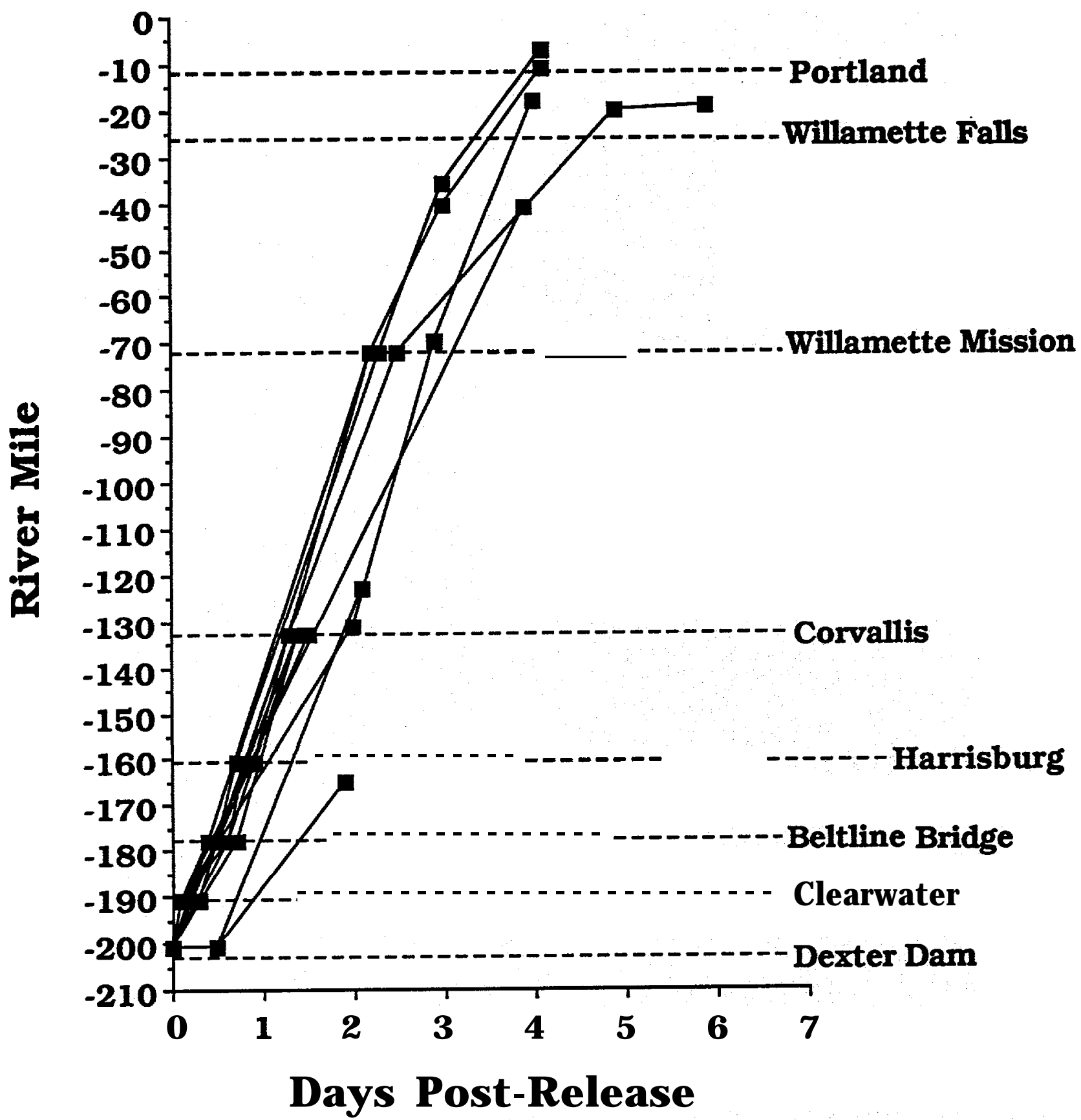

Figure 4. Movement patterns observed for radio-tagged juvenile spring chinook salmon reared at Willarnette Hatchery (1990 brood-year) in Pond \#10 North (3rd pass in the Michigan Series: triple density with $\mathrm{O}_{2}$ supplementation) and released at Pengra Ramp (Willamette River Mile 201) on 1 March 1991. N = 15 (20 fish were tagged; five tags not located after release were deleted from the data set). 


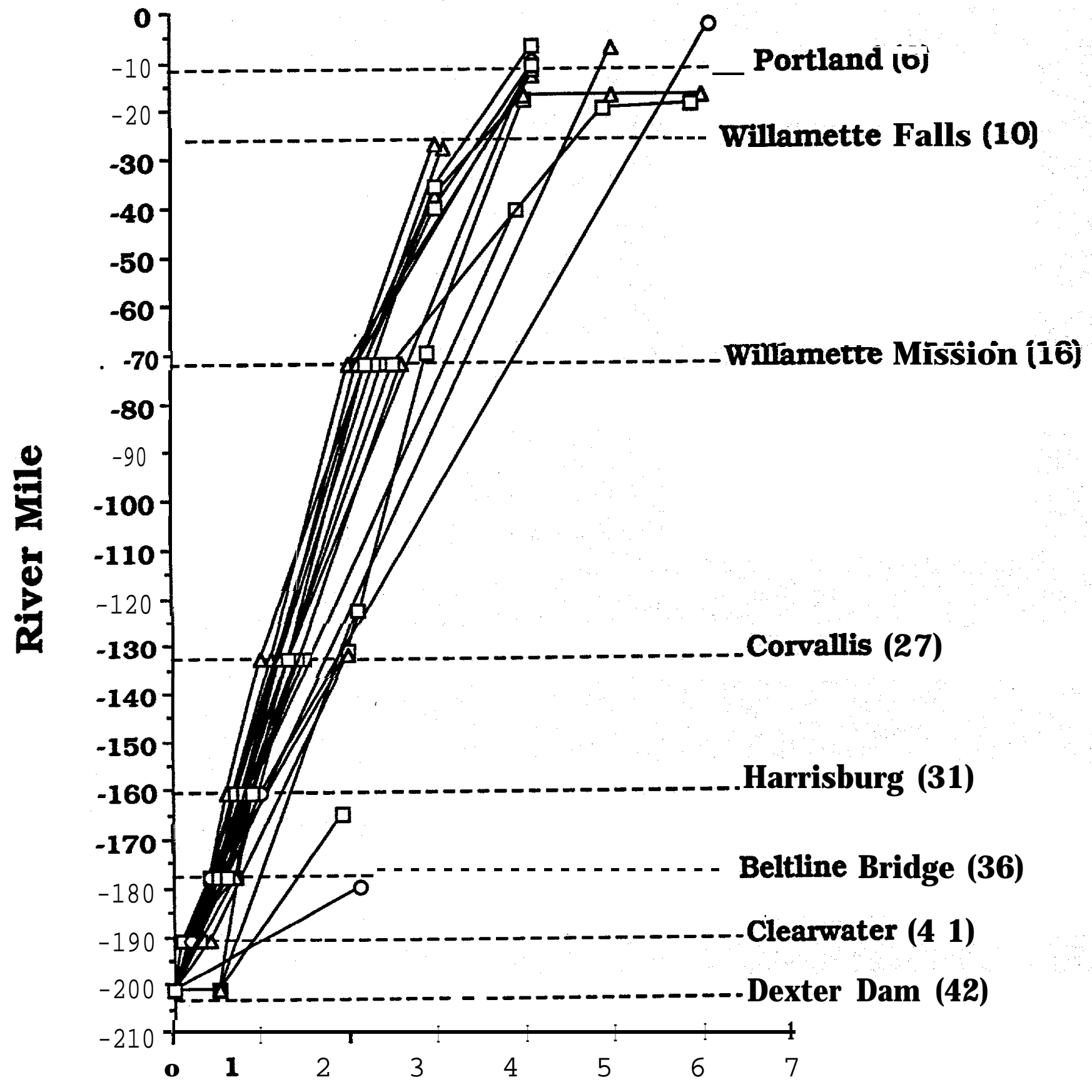

\section{Days Post-Release}

Figure 5. Movement patterns observed for radio-tagged juvenile spring chinook salmon reared at Willarnette Hatchery (1990 brood-year) and released at Pengra Ramp (Willamette River Mile 201) on 1 March 1991. Treatments are combined from Figures 2 through 4; fish were reared in Ponds \#17 (standard pond: circles), \# 19 (triple density $+\mathrm{O}_{2}$; triangles), and \# 10 North (3rd pass Michigan Series, triple density $+\mathrm{O}_{2}$; squares). Numbers in parenthesis are fish which reached indicated location. Total $\mathrm{N}=42$. 
from regression analysis of these data are summarized in Table 1 and plotted in Figure 6 together with estimates of river current velocities.

Of the 60 fish tagged with radio transmitters, 42 were successfully tracked downstream of the release site over a period of seven days. Of these, 15 represented Pond \#17 (standard pond), 12 represented Pond \#19 (triple density with supplemental oxygen), and 15 represented Pond \#10 North (3rd pass in the Michigan Series, triple density with supplemental oxygen).

Although the majority of tagged juveniles began to move downstream immediately following release, 12 fish (two from Pond \# 17, five from each of Ponds \#19 and \#10 North) remained within receiving range of the release site for at least 1.5 hours after liberation (last year, one fish of 31 remained within range for 30 minutes after release).

Fish were observed to travel at a fairly constant velocity of approximately 2 to 3 miles per hour as far downstream as Willamette Mission Park (RM 72). No differences were observed between treatment groups with respect to rate of downstream movement. In general, fish tended to travel faster in the upper river $(3.5 \mathrm{mph}$ in the vicinity of Harrisburg, RM 161), than in the lower river (1.2 mph in the vicinity of Wilsonville, RM 39). Likewise, current velocities were observed to be higher in the upper river ( 6 to $7 \mathrm{mph}$ between Pengra Ramp, RM 201, and Corvallis, RM 132) than in the lower river (2 to 3 mph below Willamette Falls). Fish velocities were consistently lower than current velocities (see Table 1 and Figure 6), indicating that the downstream movement of radio-tagged juvenile spring chinook was most likely not achieved via passive drift on the part of "migrant" fish. 
Table 1: Rate of downstream movement of radio-tagged juvenile spring chinook salmon (treatments combined), and river current velocities (Willamette River). Fish velocities derived from regression analysis of tracking data (Figure 5); water velocities estimated using a Marsh-McBirney flow meter (these data are plotted in Figure 6).

\begin{tabular}{lcccc}
\hline \multicolumn{1}{c}{ Location } & \multicolumn{2}{c}{ River River Current } & $\begin{array}{c}\text { Fish Velocity } \\
(\mathrm{mph})\end{array}$ & $\begin{array}{c}\text { (N) } \\
(\mathrm{mph}, \text { mean } \pm \text { SEM) }\end{array}$ \\
\hline Pengra Ramp & 201 & 6.95 & $2.55 \pm 0.14^{*}$ & 17 \\
Clear-water & 191 & 6.95 & $1.78 \pm 0.08$ & 24 \\
Eugene & 178 & 6.56 & $1.88 \pm 0.15$ & 10 \\
Harrisburg & 160 & 6.47 & $3.53 \pm 0.26$ & 16 \\
corvallis & 132 & 6.47 & $2.40 \pm 0.05$ & 13 \\
Wilsonville & 39 & 5.99 & $1.23 \pm 0.08$ & 6 \\
West Linn & 26 & 3.11 & & \\
Lake Oswego & 21 & 1.74 & & \\
Selwood Bridge & 16 & 1.93 & & \\
Marquam Bridge & 13 & 2.86 & & \\
\hline
\end{tabular}

*Calculated for River Mile 196 (5 miles below Pengra Ramp) 


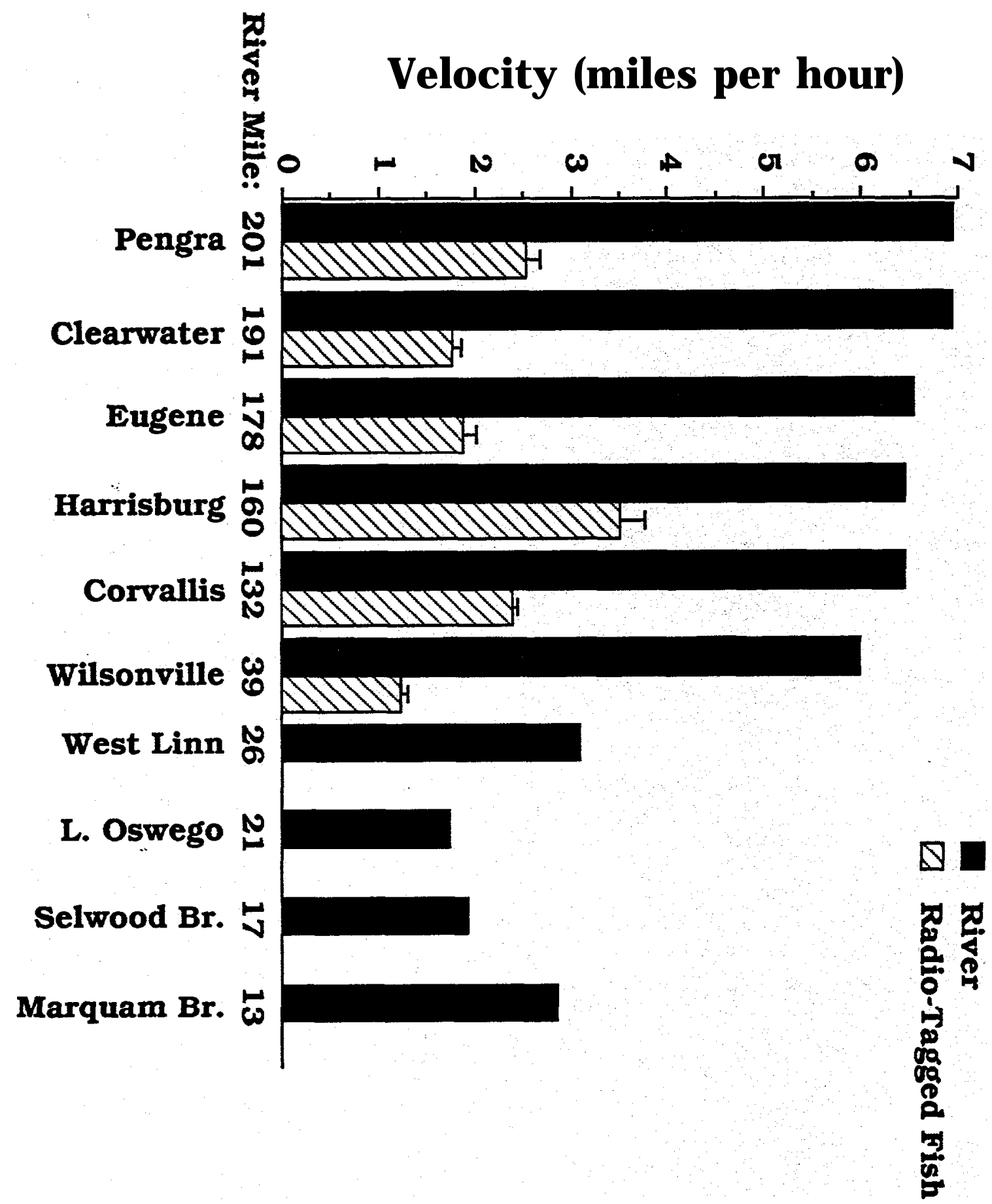

Figure 6. River current velocities (Willamette River) and rates of downstream movement observed for radio-tagged juvenile spring chinook salmon during outmigration, 199 1. Fish velocities calculated from regression analysis of tracking data (see Figures 2 - 5) ; water velocities estimated using a MarshMcBirney flow meter. Data from Table 1. 
Fish constantly varied in their relative position or "order" maintained during the outmigration. In other words, the first fish recorded past a given tracking station was not always the first fish recorded past the next station (this same observation was made in 1989 and 1990).

Water temperatures (recorded at Willamette Falls) and flow rates (recorded at Salem) characterizing the Willamette River during the . outmigration of radio-tagged juvenile spring chinook salmon are presented in Figure 7 . There was no obvious correlation between the outmigrant behavior of juveniles and either water temperatures or flows prevailing during the first week of March. Temperatures decreased slightly (from $9.5^{\circ} \mathrm{C}$ to $8{ }^{\circ} \mathrm{C}$ at Willamette -Falls) and flows increased (from $13,000 \mathrm{cfs}$ to $>55,000 \mathrm{cfs}$ at Salem) during the juvenile outrnigration.

Following the tracking strategy employed in this study, it was impossible to assess whether or not outmigrant juveniles exhibited a pronounced diel pattern with respect to downstream movement (i.e.,a tendency to move primarily during either daylight or dark conditions). It was clear, however, that fish recorded past a given river-bank tracking station were in fact moving past that point, and fish were recorded past tracking stations both during daylight and night-time hours.

\section{Recapture of Outmigrant Juveniles Above Willamette Falls}

The results of our efforts to recapture juvenile spring chinook salmon representing Willamette Hatchery production release out of 


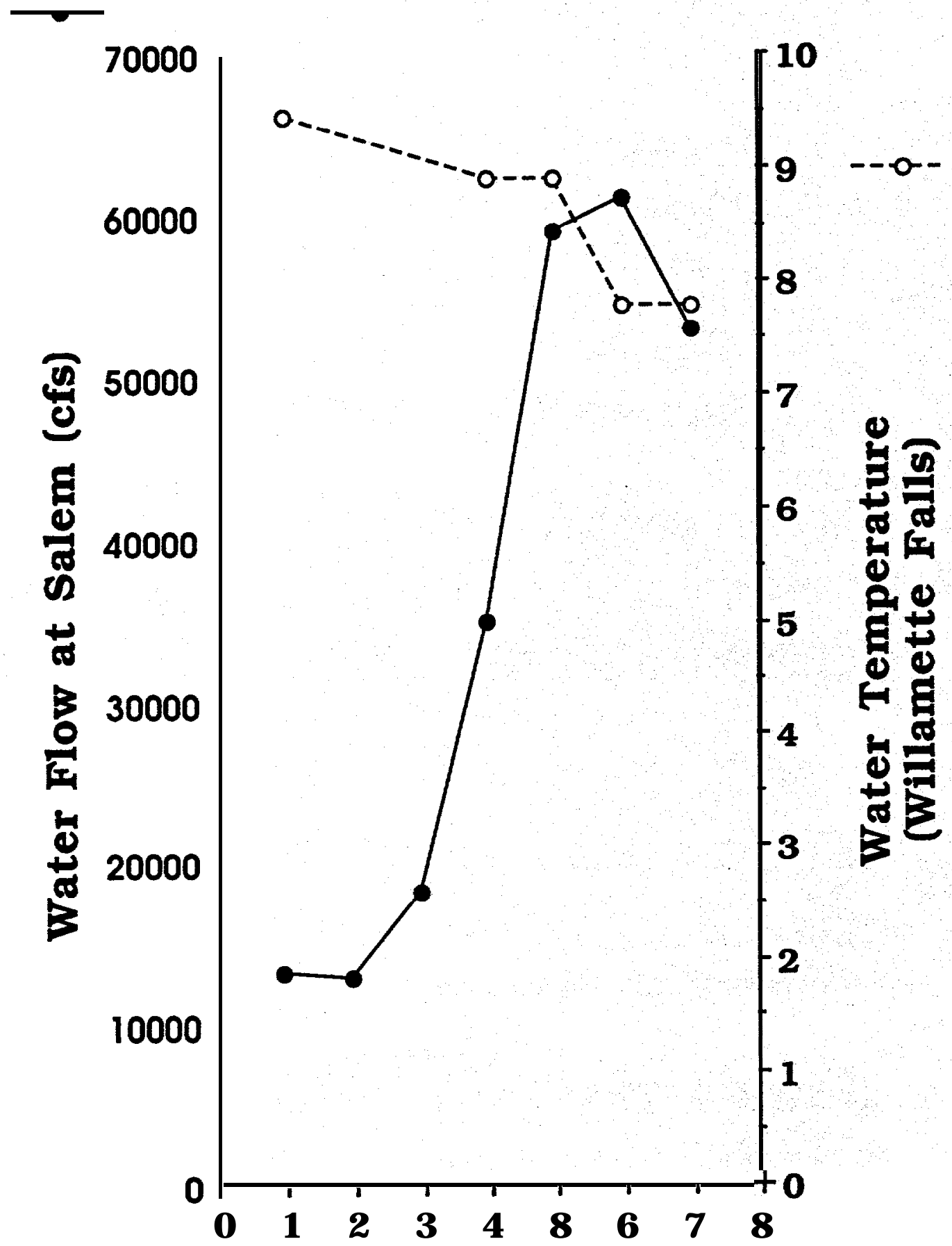

\section{Days Post-Release}

Figure 7. Water temperatures and flow rates describing the Willamette River during outmigration of radio-tagged juvenile spring chinook salmon (1-7 March, 1991). Water temperatures recorded at Willamette Falls (RM 26.5) provided by ODFW: water flows recorded at Salem (RM 84) provided by the US Geological Survey. 
Dexter Pond are listed in Table 2. Large numbers of juvenile spring chinook were also released by the McKenzie River Fish Hatchery and hatcheries on the North and South Santiams (Marion Forks and Foster) coincident with the Dexter release, so it is probable that more than one stock is represented in our data. In the area just above Willamette Falls (Peach Cove, Bernart banding and Rock Island), where we concentrated sampling efforts, the maximum number of hatchery and wild fish occurred at 15 days post release. Of interest,' Figures 3-5 show that radio-tagged fish reached this area of the river in as few as three days. If the radio-tagged fish moved with their untagged cohort, then we would expect to have captured more of the latter at Peach Cove eight days post release. Perhaps our sampling procedure was somehow deficient. After the first week of March, Willamette River flows steadily decreased. So our sampling on the 8th and 13th may have been affected by the previous flood conditions, the steadily falling river level, or both (Figure 7). But also as we observed last year, single sets or electro-shocking yielded variable success, suggesting that fish were moving together in more or less discrete aggregations. We have no reason to suspect that wild fish do not also exhibit this behavior.

\section{Evaluation of Juvenile Spring Chinook Residualism}

Table 2 presents the results of our survey for residuals during March and April. Based on the absence of juvenile spring chinook in the upper, middle and lower reaches of the Willamette later in the year for 1990 (see 1990 Annual Report), and similar findings in late 
Table 2: Summary of qualitative survey conducted at selected sites (Willamette River) to establish the presence/absence of juvenile spring chinook salmon at various times after the release of production fish from Willamette Hatchery (release date $=28$ February 1991). Numbers do not necessarily represent fish available because we chose not to disturb or take more fish than necessary for qualitative measure. CWT's $=$ Coded Wire Tags.

\begin{tabular}{|c|c|c|c|c|c|c|}
\hline Date & $\begin{array}{l}\text { Day Post } \\
\text { Hatchery } \\
\text { Release } \\
\end{array}$ & Location & $\begin{array}{r}\text { River } \\
\text { Mile }\end{array}$ & $\begin{array}{l}\text { Capture } \\
\text { Method }\end{array}$ & $\begin{array}{l}\text { (N) Fish } \\
\text { Captured }\end{array}$ & $\begin{array}{c}(\mathrm{N}) \\
\mathrm{CWT}\end{array}$ \\
\hline $3 / 08 / 91$ & 8 & Peach Cove & 32 & Seine & 13 & 6 \\
\hline $3 / 13 / 91$ & 13 & $\begin{array}{l}\text { Pengra Ramp } \\
\text { Buena Vista }\end{array}$ & $\begin{array}{l}201 \\
106\end{array}$ & $\begin{array}{l}\text { Shock } \\
\text { Shock }\end{array}$ & $\begin{array}{r}2 \\
21\end{array}$ & $\begin{array}{l}0 \\
5\end{array}$ \\
\hline $3 / 15 / 91$ & 15 & $\begin{array}{l}\text { Peach Cove } \\
\text { Bernert Landing } \\
\text { Rock Island }\end{array}$ & $\begin{array}{l}32 \\
28 \\
30\end{array}$ & $\begin{array}{l}\text { Seine } \\
\text { Shock } \\
\text { Shock }\end{array}$ & $\begin{array}{r}289 \\
36 \\
46\end{array}$ & $\begin{array}{r}60 \\
9 \\
10\end{array}$ \\
\hline $3 / 18 / 91$ & 18 & Jasper to Island Park & 190 & Shock & 1 & 0 \\
\hline $3 / 20 / 91$ & 20 & Buena Vista & 106 & Shock & 8 & 3 \\
\hline $3 / 22 / 91$ & 22 & $\begin{array}{l}\text { Peach Cove } \\
\text { Rock Island } \\
\text { Bemert Landing }\end{array}$ & $\begin{array}{l}32 \\
30 \\
28\end{array}$ & $\begin{array}{l}\text { Shock Seine } \\
\text { Shock }\end{array}$ & $\begin{array}{r}13811 \\
90\end{array}$ & $\begin{array}{r}262 \\
10\end{array}$ \\
\hline $3 / 28 / 91$ & 28 & $\begin{array}{l}\text { Buena Vista } \\
\text { Bernert Landing } \\
\text { Rock Island }\end{array}$ & $\begin{array}{r}106 \\
28 \\
30\end{array}$ & $\begin{array}{l}\text { Shock } \\
\text { Shock } \\
\text { Shock }\end{array}$ & $\begin{array}{l}87 \\
95\end{array}$ & $\begin{array}{r}0 \\
13 \\
21\end{array}$ \\
\hline $4 / 04 / 91$ & 35 & $\begin{array}{l}\text { Buena Vista } \\
\text { Bernert Landing } \\
\text { Rock Island }\end{array}$ & $\begin{array}{r}108 \\
30\end{array}$ & $\begin{array}{l}\text { Shock } \\
\text { Shock }\end{array}$ & $\begin{array}{l}63 \\
40\end{array}$ & $\begin{array}{l}0 \\
9 \\
5\end{array}$ \\
\hline $4 / 11 / 91$ & 42 & $\begin{array}{l}\text { Buena Vista } \\
\text { Bernert Landing } \\
\text { Rock Island }\end{array}$ & $\begin{array}{r}108 \\
30\end{array}$ & $\begin{array}{l}\text { Shock } \\
\text { Shock }\end{array}$ & $\begin{array}{c}1 \\
\text { (wild) }\end{array}$ & $\begin{array}{l}1 \\
0 \\
0\end{array}$ \\
\hline $4 / 18 / 91$ & 49 & Buena Vista & 106 & Shock & $\begin{array}{c}11 \\
\text { (wild) }\end{array}$ & 0 \\
\hline & & $\begin{array}{l}\text { Bemert Landing } \\
\text { Rock Island }\end{array}$ & $\begin{array}{l}28 \\
30\end{array}$ & $\begin{array}{l}\text { Shock } \\
\text { Shock }\end{array}$ & $\begin{array}{l}0 \\
0\end{array}$ & $\begin{array}{l}0 \\
0\end{array}$ \\
\hline
\end{tabular}


April 199 1, we discontinued sampling from May onward. So again we have not demonstrated any evidence of true residuals.

These data are consistent with our radio-telemetry findings. All of the radio-tagged juveniles moved away from the release site almost immediately. Two weeks post-release, electro-shocking in the release site yielded no hatchery fish and only two wild juvenile spring chinook. Shocking in the same area one week later produced only one juvenile, again a wild fish.

We were successful in capturing spring chinook smolts in the lower river through 4 May 199 1. Unlike 1990, however, no radiotagged fish lingered in the Willamette Falls area; this may be the result of high water flow during this period (see Figure 7), slightly earlier release of the fish, or perhaps slightly smaller size of the fish than in the previous year, or a combination of these factors. As for 1990, our objective in evaluating residualism was not to perform an exhaustive quantitative study of the population, but rather to qualitatively assess if fish were present at a given time and place: we did not want to disturb or take more fish than absolutely necessary. The numbers of juvenile spring chinook listed in Table 2 are not necessarily representative of numbers available.

Of the 214 fish examined all but one had food in the gut. A qualitative assessment of gut contents revealed that fish were feeding primarily on aquatic insects: stoneflies (Plecoptera), true flies (Diptera), Caddisflies (Tricoptera), amphipods, beetles (Coleoptera) and bees/ants (Hymenoptera) were the most common food items (Figure 8). 


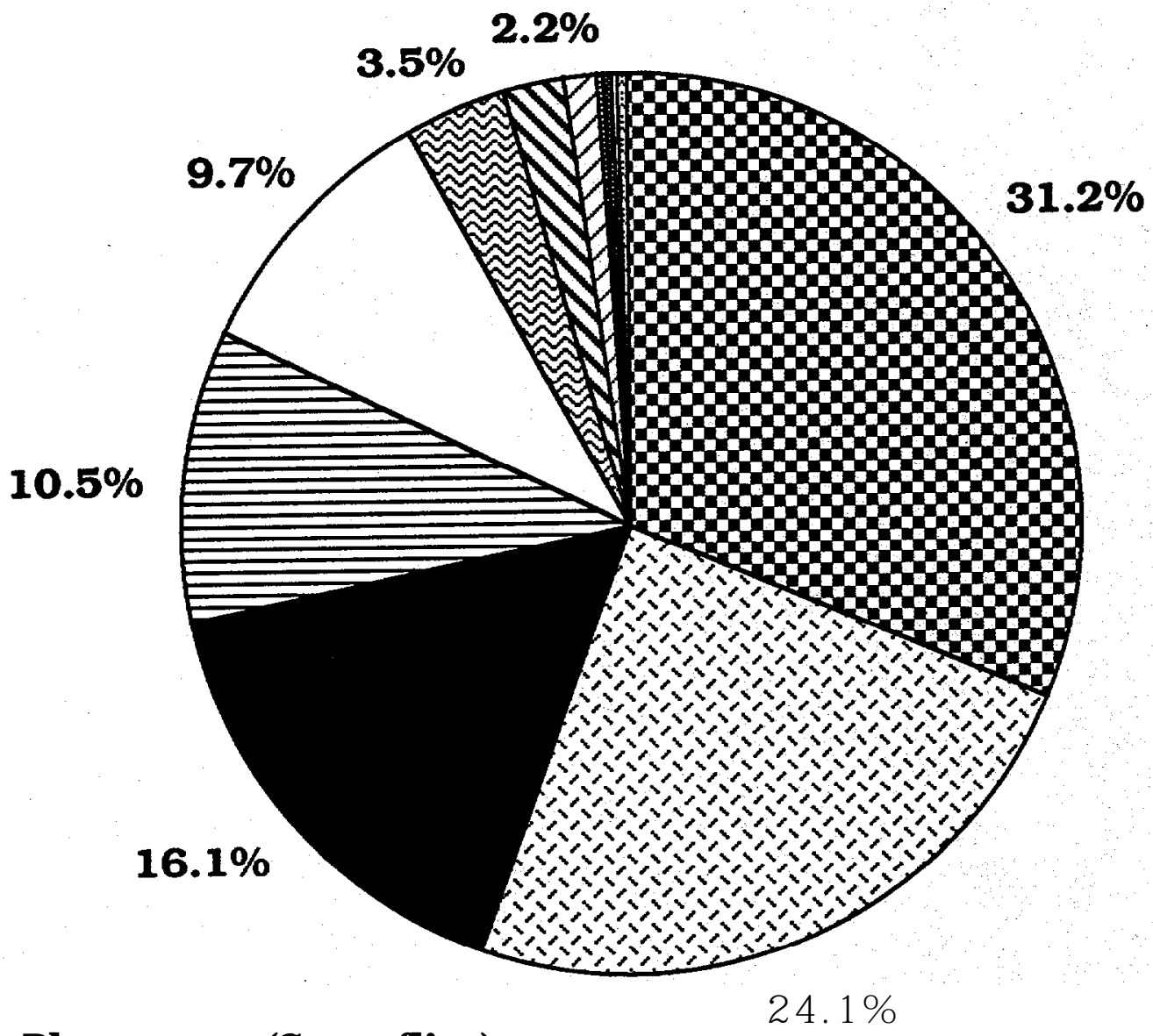

a Plecoptera (Stoneflies)

$24.1 \%$

El Unidentified Insect Parts

- Unidentified Organic Matter

a Diptera (True Flies)

Cl Tricoptera (Caddisflies)

] Amphipoda

$\square$ Coleoptera (Beetles)

Hymenoptera (Bees, Ants)

目 Hemiptera (True Bugs)

๑ Odonata (Damselflies)

口 Ephemeroptera (Mayflies)

图 Plant Matter

Figure 8. Analysis of gut contents of juvenile spring chinook salmon collected during qualitative survey of the Willamette River in 199 1. Food items are listed as percentages of total volume and arranged in relative order of abundance. Total $\mathrm{N}=213$ : see Table 2 for sample dates and locations. 
Gill $\mathrm{Na}^{+} / \mathrm{K}^{+}$ATPase activity in juvenile spring chinook salmon reared at Willamette Hatchery are presented in Figure 9. Analysis of variance suggests that there were significant differences between fish reared in the three treatment regimes. Pair-wise comparisons using Duncan's new multiple range test at the 95\% confidence level demonstrated significant $(\mathrm{p}<.05)$ differences as follows: pond 9 fish (triple dense with oxygen supplementation) $(8.4, \pm .296 \mu \mathrm{mol} \mathrm{Pi} / \mathrm{mg}$ protein $/ \mathrm{hr}$.) versus pond 10 South (third pass in Michigan series) (7.1, \pm .222 ), and pond 7 (standard density) $(7.96, \pm, 369)$ versus pond 10 South fish.

We also performed analysis of variance on the Willamette Hatchery juvenile ATPase data above and data from similarly treated fish collected in the river from 6-35 days after release. There were no significant differences between treatments, but there was a highly significant $(\mathrm{p}<$. .OOOl) elevation (more then doubling) of gill ATPase activity in fish 20 days after release. Figure 10 compares fish reared under standard conditions to illustrate the differences in ATPase activity. ATPase activity levels in juveniles reared in standard conditions in the hatchery and at several post-release sampling locations (river mile 201, 105, 30, and 28) were also significantly (pc $.0001)$ elevated the farther downriver juveniles were collected.

Fork length (size) of juveniles reared under standard conditions in the hatchery and those sampled from the river compared with gill ATPase activity, showed a negative correlation coefficient of $\mathbf{- . 2 7 8}$. The regression ANOVA which is significant at the .05 level suggests unexpectedly that in our sample larger fish have the lowest enzyme activity. 


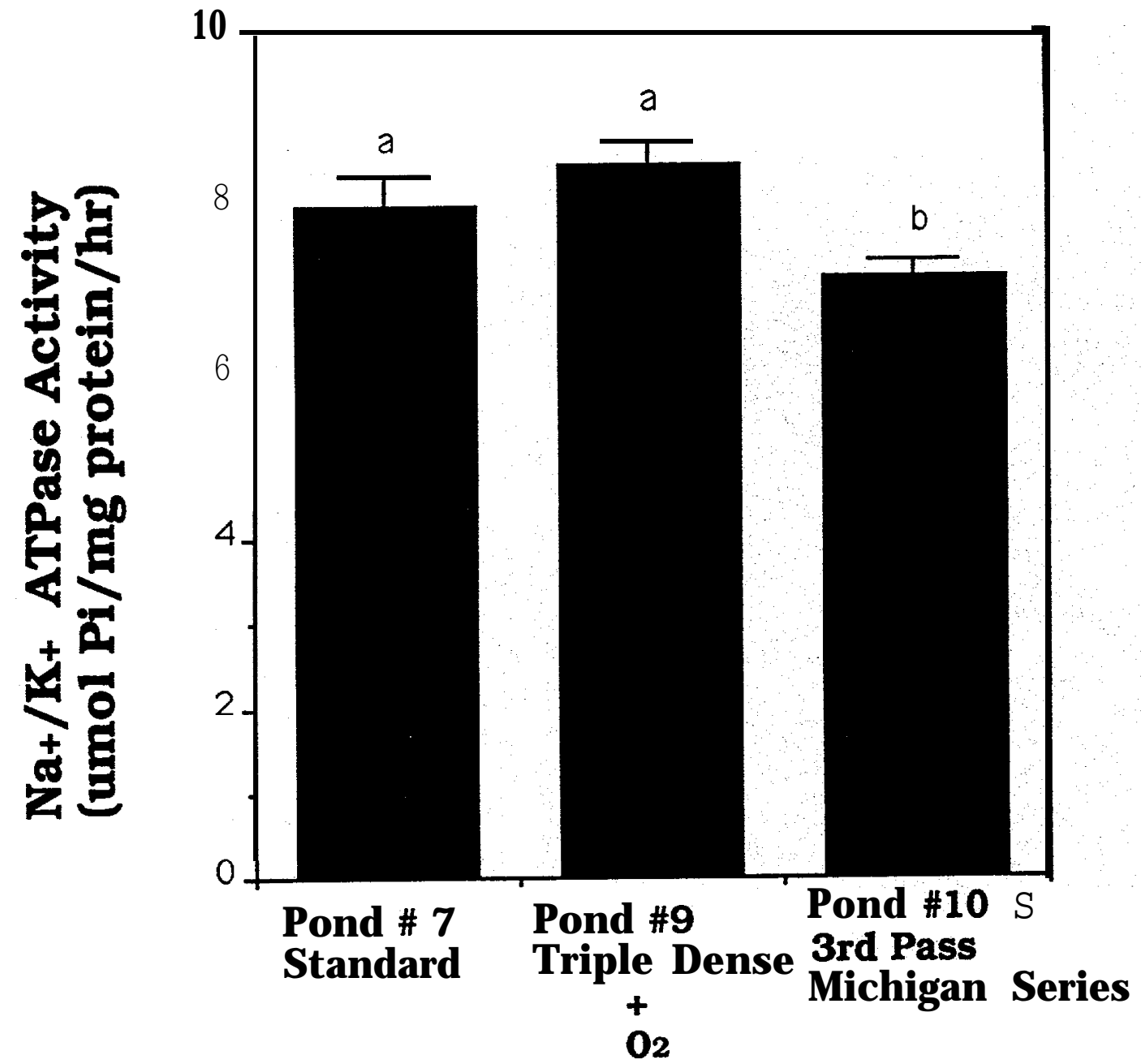

Treatment

Figure 9. $\mathrm{Na}^{+} / \mathrm{K}^{+}$ATPase from the gills of juvenile spring chinook salmon (Willamette Hatchery, 1990 brood-year) immediately before release on 28 February 1991. Histogram bars indicate the mean + $\mathrm{SE} ; \mathrm{N}=20$ for each treatment. Duncan's New Multiple Range Test showed means labeled with different letters to be statistically different $(\mathrm{p}<0.05)$. 


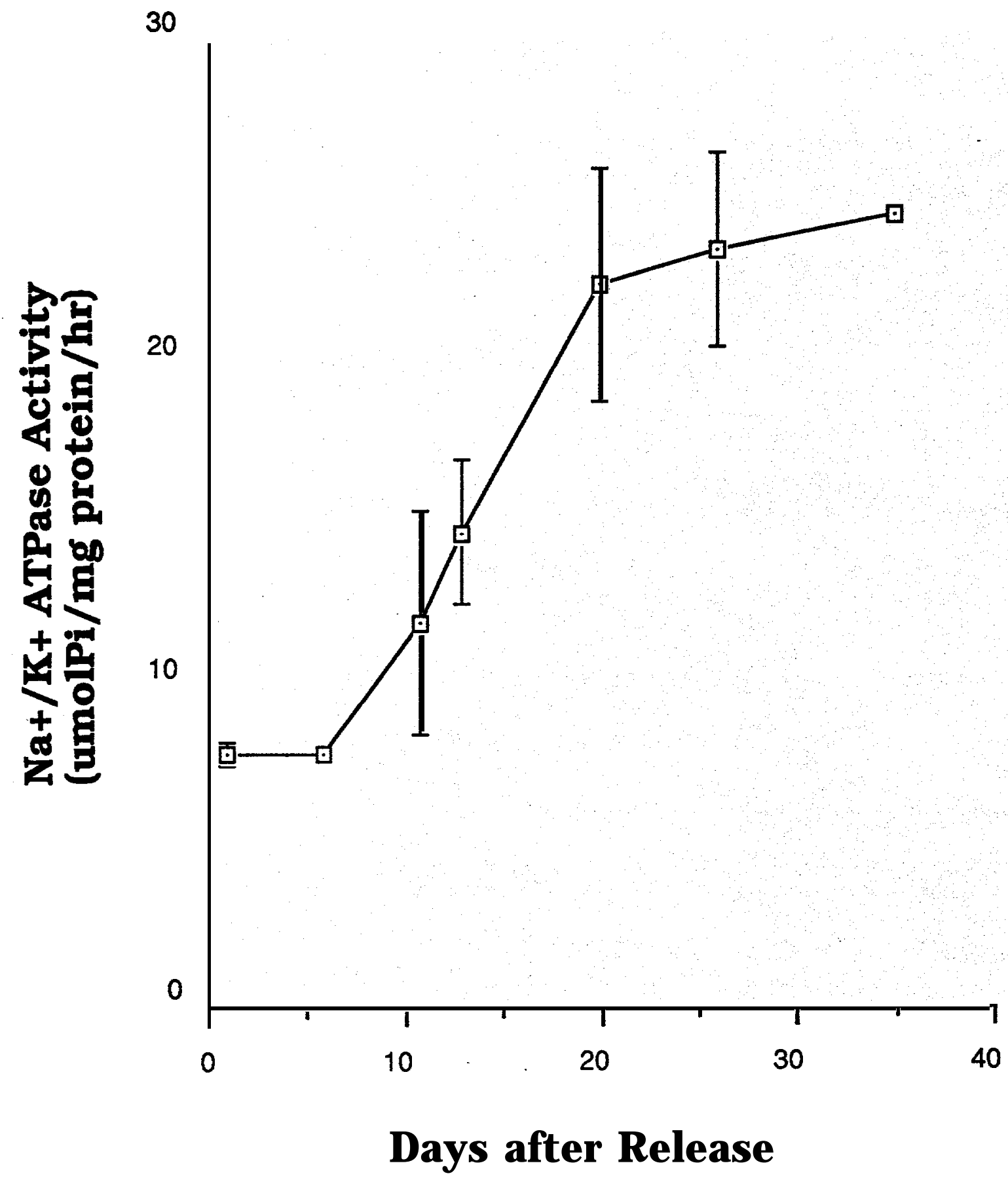

Figure 10. $\mathrm{Na}+/ \mathrm{K}+$ ATPase in the gills of juvenile spring chinook Salmon (Willamette Hatchery, 1990 brood-year) reared under standard density with no oxygen supplementation. Twenty samples were taken in the hatchery pre-release (day 1); the remaining samples were collected by beach seining or electro-shocking areas of the Willamette River above Willamette Falls, $N=1,2$, $3,2,3,1$ on days $6,11,13,20,26$, and 35 respectively. Error bars represent one stardard error. 
Comparing the cortisol (Figure 1) and the ATPase data (Figure 9) across rearing treatments shows that juvenile spring chinook salmon either reared under standard conditions or triple dense with oxygen supplementation respond similarly. But fish reared triple. dense with oxygen supplementation in the third Michigan series regime exhibit retarded development as measured by lower plasma cortisol concentration and gill ATPase activity.

As expected, juvenile spring chinook salmon show increased gill ATPase, and hense greater preparation for challenging the increased salinity of estuary conditions, either the farther they are from the release site or the older they are. In 1990 we attributed observed variation in ATPase activity to the likelihood that fish sampled downriver were from release sites other than the Willamette Hatchery. The present data, showing consistent differences in known Willamette Hatchery fish, lend credence to our previous explanation.

\section{Radio-tracking Returning Adults}

Table 3 (length, weight, age for both 1990 and 1991) and figures 11- 14 present the data we collected while tagging and monitoring the upriver progress of adult spring chinook salmon during the return, or spawning migration. Data are expressed in distance traveled as a function of time: the slope of any line gives the average velocity in a given stretch of river. Water temperatures (recorded at Willamette Falls) and flow rates (recorded at Salem) characterizing the Willamette River during the various phases of the adult migration are shown in Figure 15. Daily and cumulative counts of adult spring chinook salmon 
Table 3. Descriptions of adult spring chinook salmon captured, tagged with radio transmitters, and released into the fish ladder at Willamette Falls (River Mile 26.5) during 1990 and 1991.

\begin{tabular}{|c|c|c|c|c|c|c|c|c|}
\hline \multirow[b]{2}{*}{ Year } & \multirow[b]{2}{*}{ Run } & \multirow{2}{*}{$\begin{array}{c}\text { Date Fish } \\
\text { Tagged }\end{array}$} & \multirow{2}{*}{$\begin{array}{c}\text { No. of Fish } \\
\text { Tagged }\end{array}$} & \multicolumn{2}{|c|}{ Length $(\mathrm{cm})$} & \multicolumn{2}{|c|}{ Weight (kg) } & \multirow{2}{*}{$\begin{array}{c}\text { Age } \\
\text { (Range) }\end{array}$} \\
\hline & & & & Average & Range & Average & Range & \\
\hline \multirow[t]{3}{*}{1990} & Early & 20 April & 15 & 81.3 & $68.0-95.0$ & 8.4 & 4.8- 12.3 & $3^{+}-4^{+}$ \\
\hline & Middle & 23 May & 17 & 90.0 & $72.0-92.0$ & 7.6 & 5.0- 13.0 & $3^{+}-4^{+}$ \\
\hline & Late & 25.June & 19 & 83.5 & $65.0-99.0$ & 9.3 & 5.3- 14.8 & $3^{+}-4^{+}$ \\
\hline \multirow[t]{3}{*}{1991} & Early & 23 April & 27 & 82.9 & $64.0-99.0$ & --- & --- & --- \\
\hline & Middle & 28 May & 28 & 80.3 & $65.0-102.0$ & 7.8 & 4.3- 14.8 & $3-4^{+}$ \\
\hline & Late & 26 June & 30 & 85.0 & $72.0-106.0$ & 8.9 & $4.0-16.8$ & $3^{+-4^{+}}$ \\
\hline
\end{tabular}




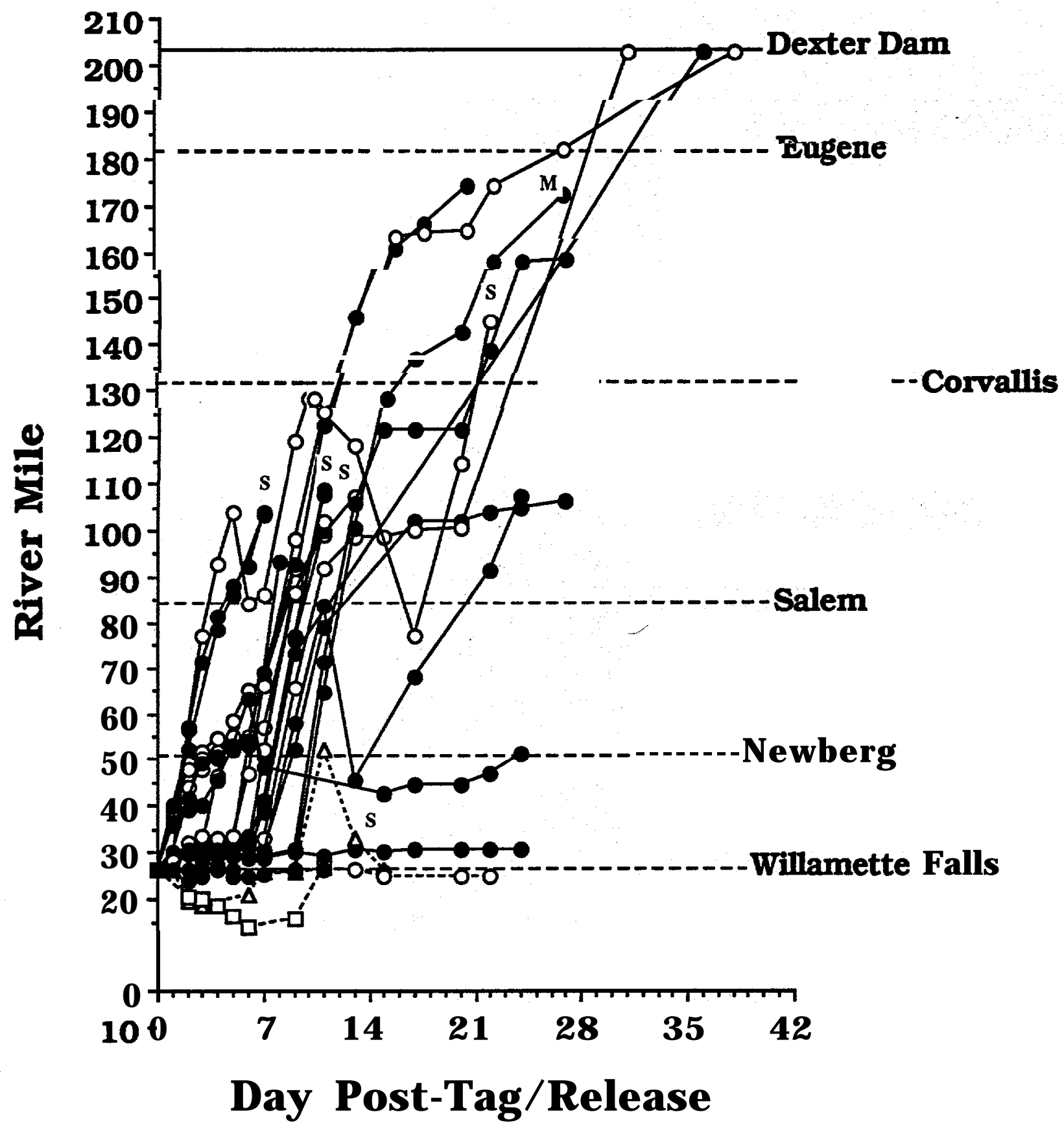

Figure 11. Movement patterns observed for radio-tagged Early-Run adult spring chinook salmon in the Willamette River, 1991. Day $0=$ 23 April: $\mathrm{N}=26$ (27 fish were tagged: one tag which did not move from the tagging site was deleted from the data set). Open and closed circles used to help clarify individual movement patterns; dashed lines emphasize individual fish observed to move downstream or fall-back below Willamette Falls. The letter (S) identifies individual fish subsequently found in the Santiam River; the letter $(\mathrm{M})$ identifies fish subsequently found in the McKenzie River. Squares and triangles indicate behavior of fish suspected of making multiple passes through the Willamette Falls fishway (see Figure 12 for details). 


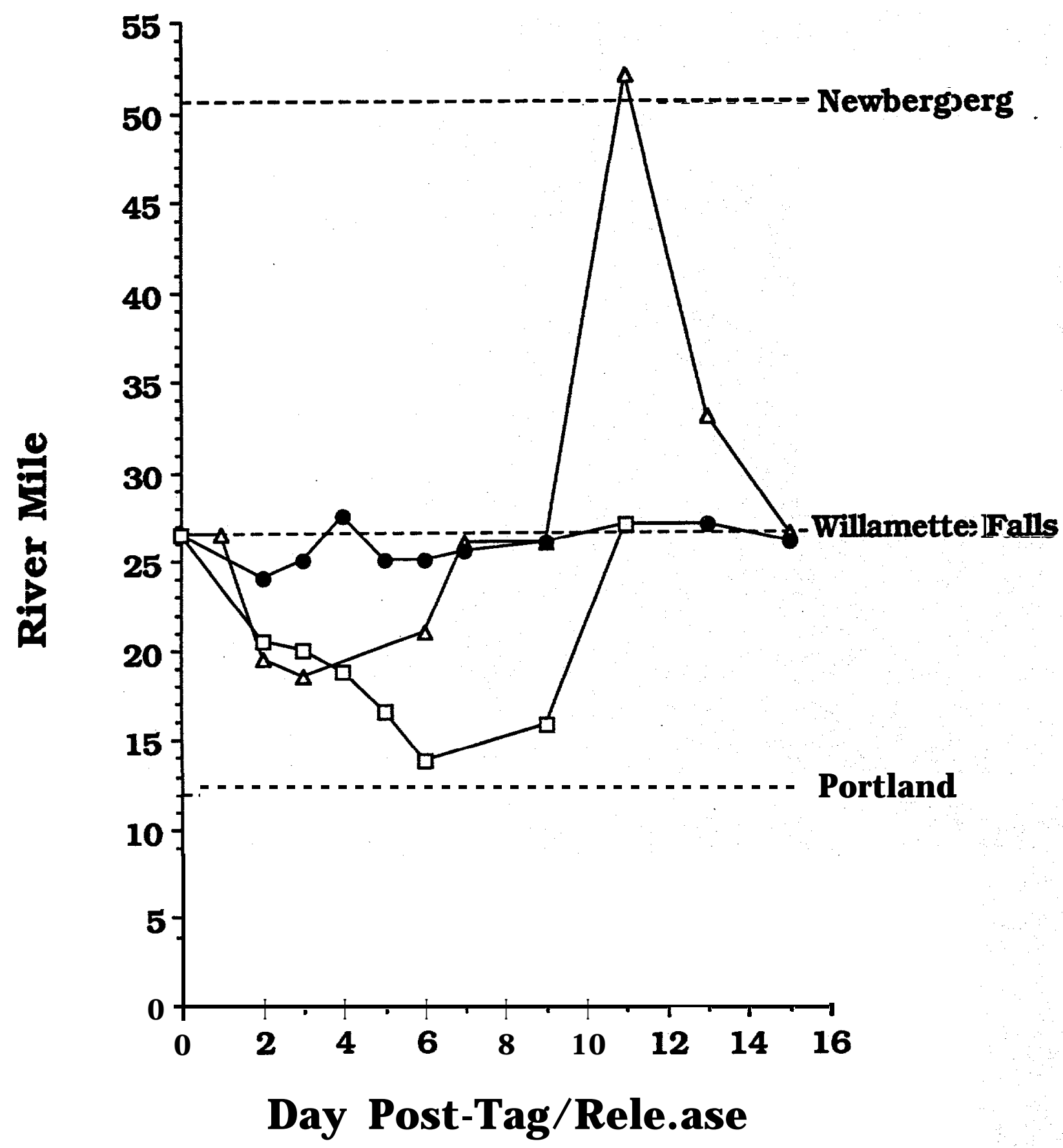

Figure 12. Detail from Figure 11 showing movement patterns observed for three radio-tagged Early-Run adult spring chinook salmon which fell-back below Willamette Falls and subsequently made one (squares and triangles) or two (circles) additional passes through the Willamette Falls fishway. 


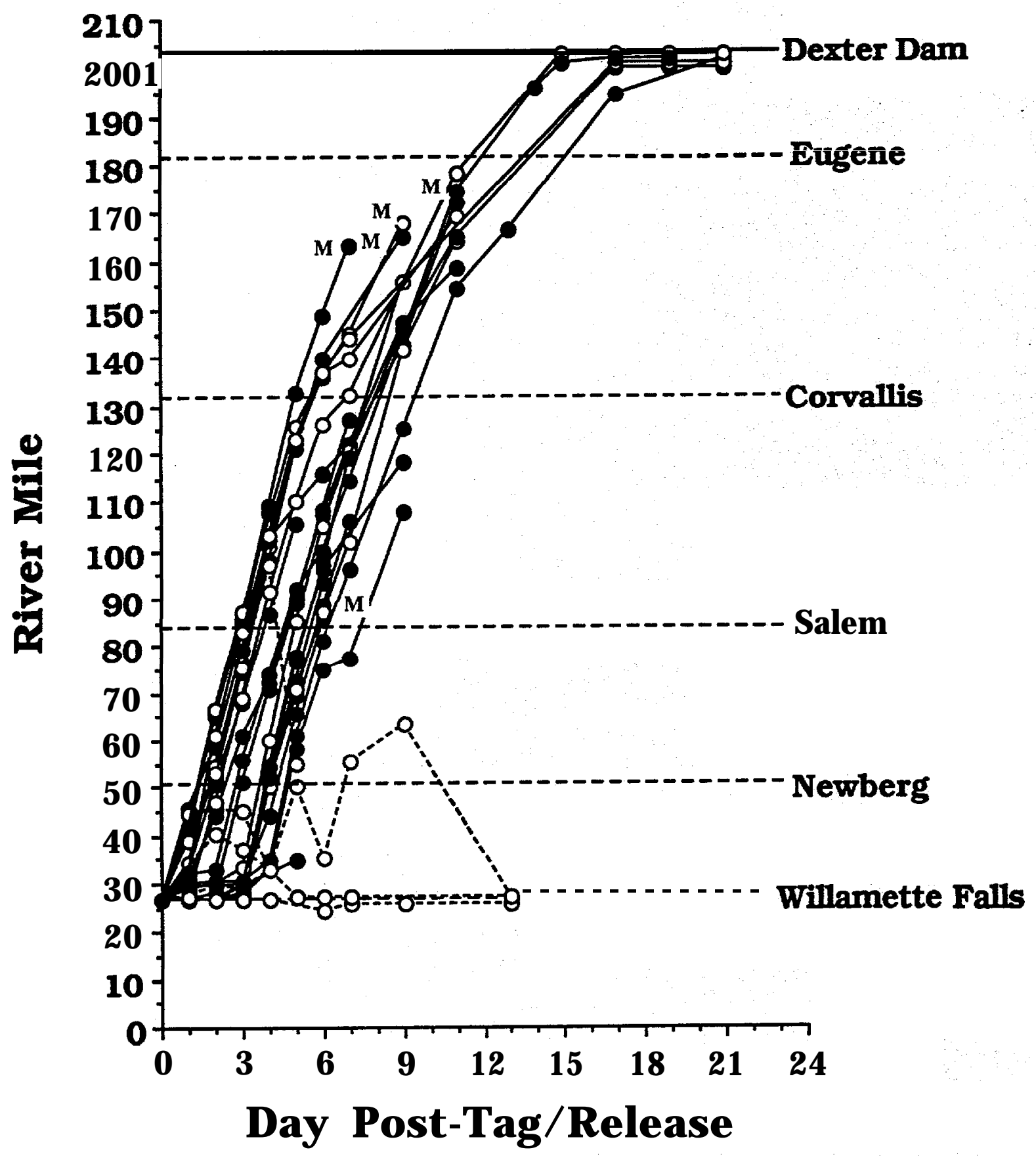

Figure 13. Movement patterns observed for radio-tagged Middle-Run adult spring chinook salmon in the Willamette River, 1991 . Day $0=$ 28 May: $\mathrm{N}=27$ (28 fish were tagged: one tag which did not move from the tagging site was deleted from the data set). Open and closed circles used to help clarify individual movement patterns; dashed lines emphasize individual fish observed to move downstream or fall-back below Willamette Falls. The letter (M) identifies individual fish subsequently found in the McKenzie River. 


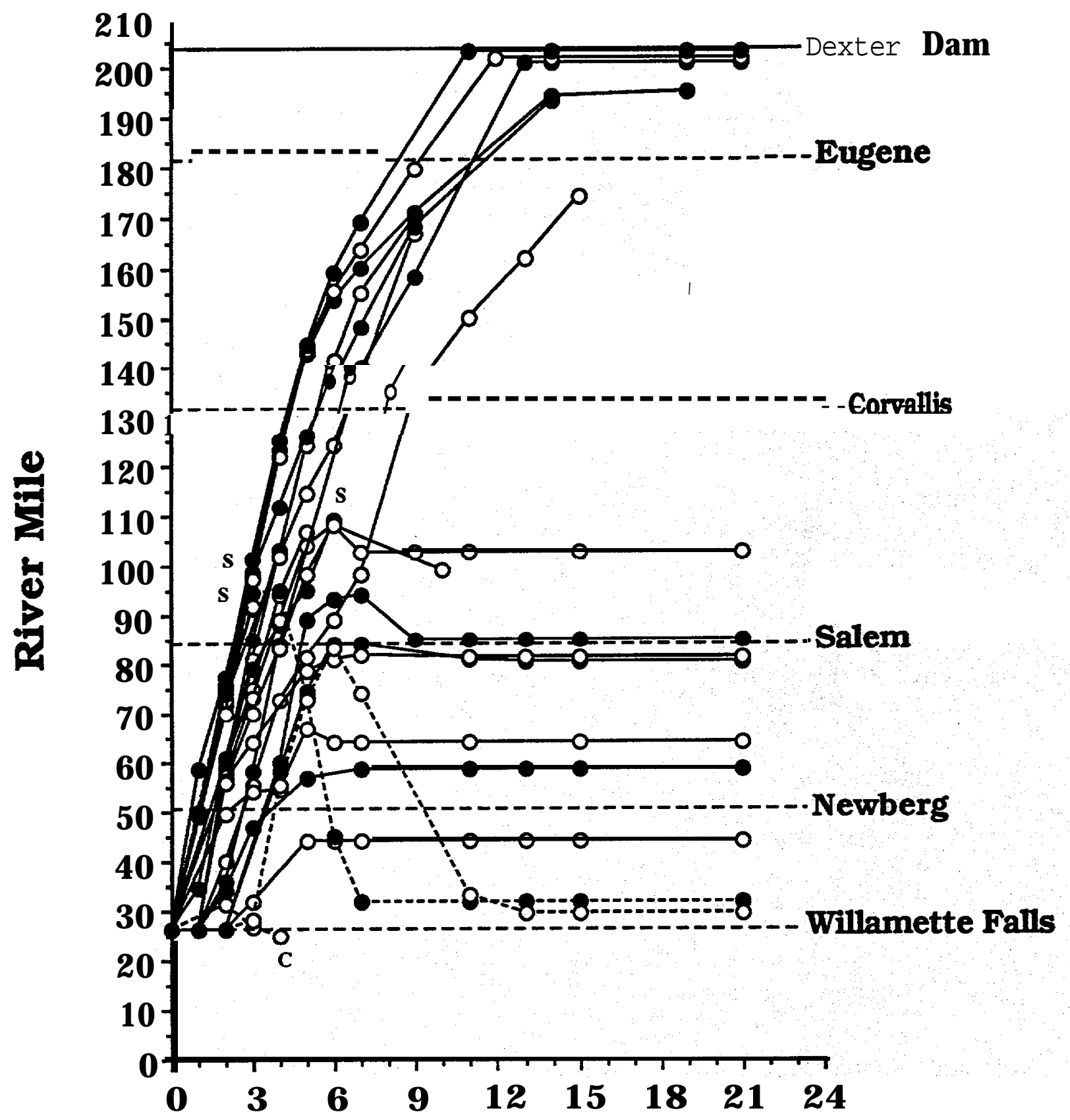

Day Post-Tag/Release

Figure 14. Movement-patterns observed for radio-tagged Late-Run adult spring chinook salmon in the Willamette River, 1991. Day $0=$ 26 June; $\mathrm{N}=24$ (30 fish were tagged: four tags which did not move from the tagging site and two tags which could not be located after tagging were deleted from the data set). Open and closed circles used to help clarify individual movement patterns; dashed lines emphasize individual fish observed to move downstream or fall-back below Willamette Falls. The letter (S) identifies individual fish subsequently found in the Santiam River: the letter (C) identifies one fish subsequently found in the Clackamas River. 
recorded past the main viewing window of the Willamette Falls fishway are shown in Figure 16 (data provided by ODFW).

We intensively tracked 26 early run adults for about 1 month starting 23 April (Figure 11); a 27th fish died in the fishway and we excluded it from the data. The day after tagging eight fish had exited the fishway. Salmon moved an average of about 10 miles per day during the first 3 weeks. Five fish remained in the fishway for at least 1 day; one remained there for six days. One fish traveled 14 miles the first day.

Six fish made considerable progress upstream (i.e. past Corvallis) Five fish traveled up the Santiam system, presumably to spawn there. One fish swam up the McKenzie River. Three were recorded by our data logger near the trap below Dexter Dam. A reward message on the radio-tags led to the recovery of 10 tags. One fish was recovered in the trap at McKenzie River Hatchery, and one below Dexter Pond on the Willamette. The others were caught by anglers, all about 10 days after tagging: one on the South Santiam, one between Independence and Salem on the Willamette, four on the North Santiam, one on the McKenzie, and one in the Santiarn system (location unknown).

The fastest fish traveled 24 miles in one day (and was caught the next day by an angler). Seven fish remained about four miles above Willamette Falls for at least four days. Similar to last year, three fish moved downstream, not up (Figure 12). One swam six miles below the falls before traveling up to Newberg and then back to the falls. None of these fish made a net gain in passage upstream, and all were last recorded in the vicinity of the falls. 
We tracked 27 mid-run adults for about three weeks after they were tagged on 28 May: a 28th fish presumably died in the fishway (Figure 13). Seven fish remained in the fishway for up to four days before moving on. The lead fish moved 19 miles upstream on the first day. The average speed of the group was 15 miles per day, showing as last year the more directed migration of mid-run spring chinook salmon. The three fastest fish each covered 23 miles in a single day. Once past the mouth of the McKenzie, fish traveled upriver at a reduced rate (about six miles each day).

Thirteen fish traveled up the Willamette as far as Corvallis. Five were logged in the vicinity of Dexter Dam, and five were heard in the McKenzie. Our reward tags helped recover four of these mid-run fish. Two were trapped at Dexter, and one at McKenzie River Fish Hatchery: the fourth was caught by an angler near Dexter.

As we observed last year, these mid-run salmon moved more rapidly and with far less individual variability than their early-run or late-run counterparts. But like the previous year's cohort, three fish traveled upriver, one as far as 36.5 miles, only to return to the Falls (dotted lines on Figure 13).

We tracked 24 late-run adult spring chinook salmon tagged on 26 June for about three weeks: six other fish either died or their tags did (Figure 14). Half of these fish traveled like their mid-run counterparts, but the remainder swam no further than Salem; presumably they died here.

Eleven fish remained in the raceway for two to three days after tagging. The fastest fish swam 32 miles in one day. Three fish entered the Santiam system. Only three reached Dexter. Three fish 
made no significant net progress above Willamette Falls, although one traveled 10 miles upstream of Salem before turning and going back to the Falls. One fish dropped back over the Falls, swam up the Clackamas, and was then caught by an angler.

Our grouping of tagged adults into three sets is supported by the daily fish passage supplied by ODFW which shows three peaks in the 1991 spring chinook run (Figure 15). It may be significant to note that nine of 77 fish (12\%) were counted at least twice as they moved over and then back down Willamette Falls. The same number of fish in each of our groups showed this behavior. In any case, these data may help account for the discrepancy between spring chinook counted at Willamette Falls and fewer adults returning to the hatcheries upriver.

Our 1990 annual report presented data showing similar patterns of adult migration: i.e., early run fish migrated slowly with much individual variation, mid-run fish migrated rapidly and uniformly, and late-run fish migrated rapidly at first until half of them halted their migration (died?). We hypothesized that the early run fish were influenced by flood conditions and associated water quality degradation (turbidity and lower temperature). Late run fish were probably influenced by the increase in water temperature: we observed many dead chinook along the river at this time.

Flood conditions $(65,000 \mathrm{cfs})$ and low water temperature $\left(10^{\circ} \mathrm{C}\right)$ occurred about 20 May 1991 (Figure 16). This period corresponded to the end of our tracking early-run adult spring chinook. Some radiotagged fish had previously ceased migration, and the remainder were already high in the river (between Corvallis and Eugene). We expect 
that a group of spring chinook negotiating the lower river at this time would have exhibited markedly reduced rates of migration.

During the week of 12 June 1991 water temperature at Willamette . Falls rose to $19^{\circ} \mathrm{C}$ (Figure 16). This period corresponds to the end of our tracking mid-run fish and prior to the late-run tracking.

Thereafter temperatures gradually increased and flows decreased.

Reduced flows and increased clarity might force fish, which previously had moved at all hours of the day, to only move now at night.

Increased temperatures would promote fungal growth and increase other disease processes. Both factors would explain the type of migration shown in Figure 15.

\section{LITERATURE CITED}

Barton, B.A., R.E. Peter, and C.R. Paulencu. (1980). Plasma cortisol levels of fingerling rainbow trout (Salmo gairdneri) at rest, and subjected to handling, confinement, transport, and stocking. Canadian Journal of Fisheries and Aquatic Sciences, 37:805-8 11.

Barton, B.A., C.B. Schreck, R.D. Ewing, A.R. Hemmingsen, and R. Patino. (1985). Changes in plasma cortisol during stress and smoltification in Coho Salmon, Oncorhynchus kisutch. General and Comparative Endocrinology, 59: 468-47 1.

Butler, D.G. (1968). Hormonal control of gluconeogenesis in the North American eel (Anguilla rostrata). General and Comparative Endocrinology, 10:85-91.

Donaldson, E.M. (1981). The pituitary-interrenal axis as an indicator of stress in fish. In: Stress and Fish (A.D. Pickering, ed.), pp. 1147. London and New York, Academic Press.

Ellis, A.E. (1981). Stress and modulation of defence mechanisms in fish. In: Stress and Fish (A.D. Pickering, ed.), pp. 147-169.' London and New York, Academic Press. 


\section{Adult Chinook Salmon}

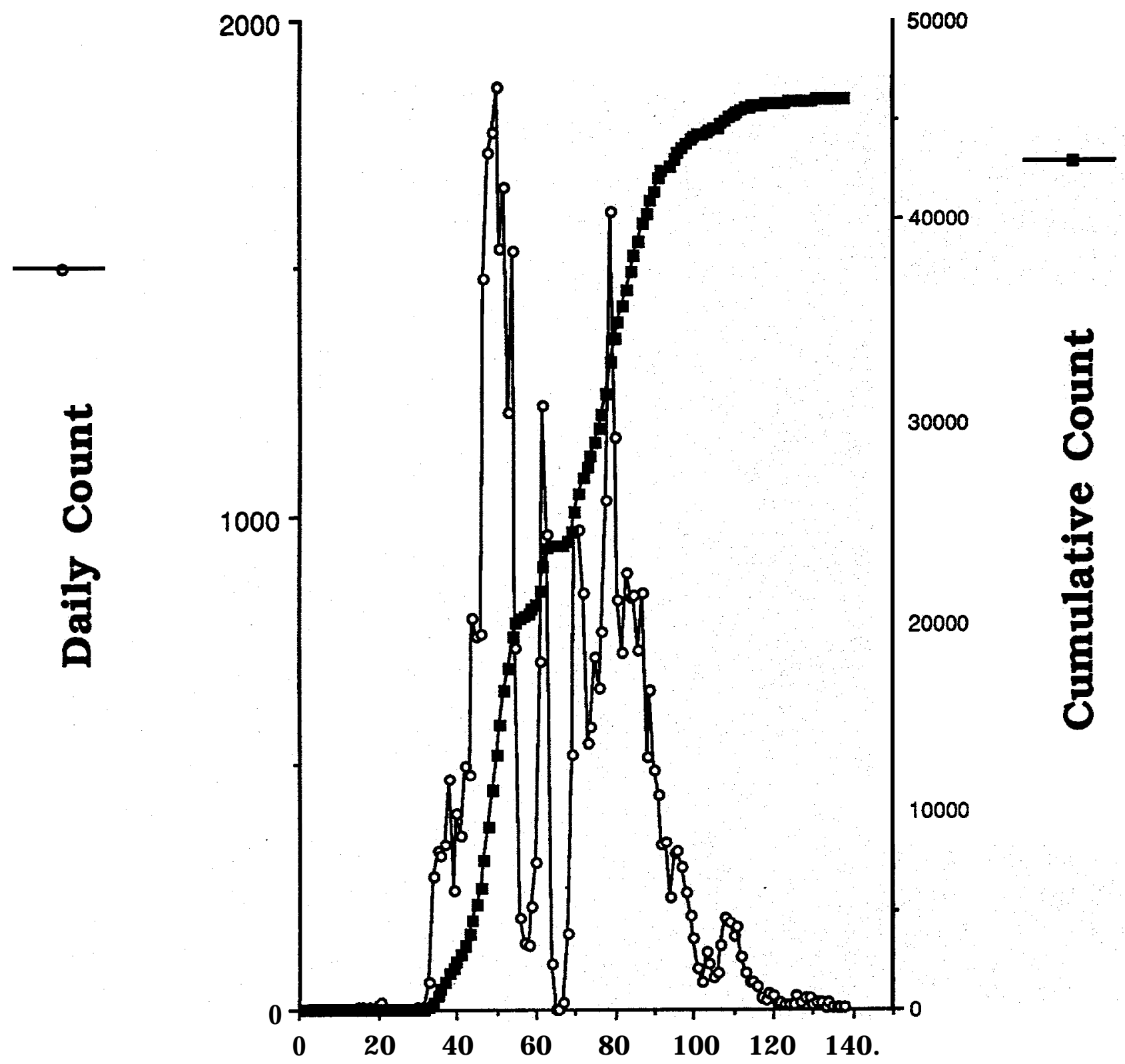

DAYS BEGINNING 1 APRIL 1991

Figure 15. Daily and cumulative counts of adult spring chinook salmon recorded past the main viewing window at Willamette Falls during the various phases of the return migration (April through July, 1991). Data provided by ODFW. 


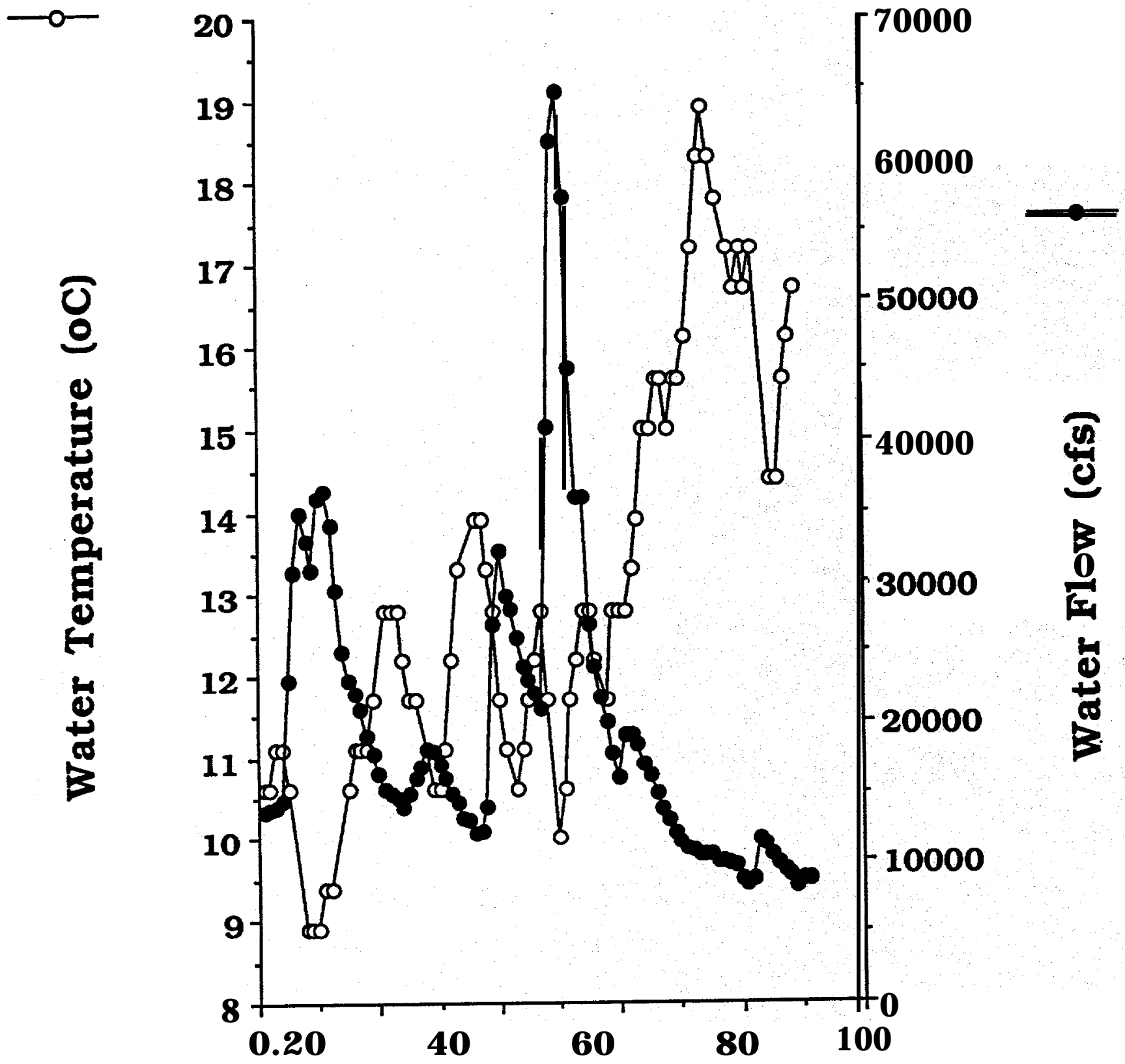

Days Beginning 1 April 1991

Figure 16. Water temperatures and flow rates describing the Willamette River during the various phases of the return migration of adult spring chinook salmon between 1 April and 18 July, 1991. Water temperatures recorded at Willamette Falls (RM 26.5) provided by ODFW; water flows recorded at Salem (RM 84) provided by the US Geological Survey. 
Foster, L.B., and RT. Dunn. (1974). Single-antibody technique for radioimmunoassay of cortisol in unextracted serum or plasma. Clincal Chemistry, 20:365-368.

Freeman, H.C., and D.R. Idler. (1973). Effects of corticosteroids on liver transaminases in two salmonids, the rainbow trout (Salmo gairdnerii) and the brook trout (Salvelinus fontinalis). General and Comparative Endocrinology, 20:69-75.

Giles, M.A., and W.E. Vanstone. (1976). Changes in ouabain-sensitive adenosine triphosphatase activity in gills of coho salmon Oncorhynchus kisutch during parr-smolt transformation. Journal of the Fisheries Research Board of Canada, 33:54-62.

Leach, G. J., and M.H. Taylor. (1980). The role of cortisol in stressinduced metabolic changes in Fundulus heteroclitus. General and Comparative Endocrinology, 42:219-227.

Maule, A.G., C.B. Schreck, C.S. Bradford, and B.A. Barton. (1988). The physiological effects of the collection and transportation of emigrating juvenile chinook salmon past darns on the Columbia River. Transactions of the American Fisheries Society, 117:245-26 1 .

Mazeaud, M.M., F. Mazeaud, and E.M. Donaldson. (1977). Primary and secondary effects of stress in fish: some new data with a general review. Transactions of the American Fisheries Society, 106:201-212.

Redding, J.M., C.B. Schreck, E.K. Birks, and RD. Ewing. (1984). Cortisol and its effects on plasma thyroid hormone and electrolyte concentrations in fresh water and during seawater acclimation in yearling coho salmon, Oncorhynchus kisutch. General and Comparative Endocrinology, 56: 146- 155.

Selye, H. (1950). Stress and the general adaptation syndrome. British Medical Journal, 1:1383-1392.

Storer, J.H. (1967). Starvation and the effects of cortisol in the goldfish (Carassius auratus L.). Comparative Biochemistry and Physiology, A 50:77-82.

Swallow, R.L., and W.R. Fleming. (1970). The effect of oxaloacetate, ACTH. and cortisol on the liver glycogen levels of Tilapia mossambica. Comparative Biochemistry. and Physiology, 36:93-98. 
Ward, D.L. and L.M. Miller. (1988). Using radio telemetry in fisheries investigations. Oregon Department of Fish and Wildlife (Fish Division) Information Reports, No. 88-7.

Zaugg, W.S. (1982). A simplified preparation for adenosine triphosphatase determination in gill tissue. Canadian Journal of Fisheries and Aquatic Sciences, 39:215-217. 